\title{
Domestic Violence Against Women in the Effutu Municipalityin the Central Region of Ghana: Implications for Counselling
}

\author{
Phoebe Agyei (Ms) and Rev. Kwesi Nkum Wilson (PhD)
}

Department of Social Welfare, Effutu Municipality

Department of Psychology and Education, University of Education, Winneba

\section{ABSTRACT}

The study investigated the prevalence of domestic violence within the Effutu Municipality, it also examined how counselling programmes can assist in addressing domestic violence within the municipality. The study employed a cross sectional survey design and collected both quantitative and qualitative data. A sim- Winneba

ple random sampling technique was used in the selection of 300 respondents for the quantitative study, while purposive sampling technique was used in the selection of 12 interviewees for the qualitative aspect of the study. Quantitative data collected were analysed using descriptive and inferential analysis while qualitative data was analysed using content and thematic analyses. The study revealed that Christians and traditionalists differed in their views with regards to cultural and life-time perceptions about domestic violence. Additionally, educational level attained also influenced respondents' perceptions on domestic violence against women in the Effutu Municipality. It was also revealed that though, there are institutions that offer services to reduce or forestall the incidence of domestic violence; both victims and perpetrators did not receive any counselling in any form. It is therefore recommended that Effutu municipal assembly hire professionally trained counsellors, and attach them to the various institutions that deal with issues bordering on domestic violence.

${ }^{*}$ Correspondence to Author:

Rev. Kwesi Nkum Wilson

Department of Psychology and Education, University of Education,

How to cite this article:

Phoebe Agyei and Rev. Kwesi Nkum Wilson. Domestic Violence Against Women in the Effutu Municipalityin the Central Region of Ghana: Implications for Counselling. American Journal of Educational Research and Reviews, 2018,3:15.

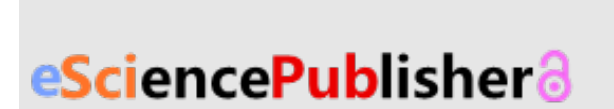

eSciPub LLC, Houston, TX USA. Website: http://escipub.com/

Keywords: Domestic Violence, Women and Counselling 


\section{Background to the Study}

African women have been exposed to domestic violence for a very long time. In some African societies, the birth of a female child is met with mixed feelings as compared with the birth of a male child. Her inner abilities and talents may not be discovered and nurtured (Akintunde \& Labeodan, 2002). With regard to women, lack of economic resources underpins their vulnerability to violence and their difficulty in freeing themselves from violent relationships. Traditionally women can seek redress when abused by their partners at three different levels; family or household head, clan level and chief or head of the community. At all these levels, the procedure used in administering justice and empanelling of the decision makers do not favour women as they usually tend not to be fair (FIDA-GHANA 2011).

Without denying the fact that men can also be victims of domestic violence, in most cases, the victim is a female. Domestic violence has been acknowledged as one of the greatest threats to female health and safety worldwide, (GarciaMoreno, Heise, Ellsberg, Jansen \& Watts, 2005). Yet few interventions have been developed and systematically studied (Chandra, Krishnan, Nancy, \& Subbiah, 2012). Domestic violence has been viewed for a long period of time as a private family matter and external sources of support and social intervention have not been adequately provided. For instance, in their study on contextualising domestic violence as public matter, Rasool and Hochfeld (2005) found out that the occurrence of abuse does not happen behind closed doors in that often those in the survivors' immediate surroundings are aware of the incidence of violence even if they do not witness it

In 1993, the United Nations' Declaration on the Elimination of Violence against Women defined violence against women as " any act of genderbased violence that results in, or is likely to result in physical, sexual or psychological harm or suffering to women, including threats of such acts, coercion or arbitrary deprivation of liberty, whether occurring in public or in private life". The World Health Organisation (WHO) also defines spousal violence or abuse as occurring when a partner tries to physically or psychologically dominate another.

Domestic Violence against Women can also be defined as any act of gender based-based violence that happens within the domestic setting which results in or is likely to result in physical, sexual or psychological harm or suffering to women, including threats of such acts, coercion or arbitrary deprivation of liberty, whether occurring in public or in private life (Amaral, 2011). Domestic violence encompasses a set of symptoms that may involve physical, emotional and or psychological abuse (FIDA- GHANA, 2013).

Young African women are faced with high incidence of rape and sexual harassment just when they are blossoming and they dare not complain or report to any higher authority for redress, (Flood 2007). In some African cultures, for instance, unquestioned authority is reposed in the male and the female is expected to acquiesce under all circumstances. It is normally viewed as disrespect when the female tries to stand for her right in relation to the male, (Akintunde et al, 2002), especially in the domestic setting and for many young people, sexual harassment and male aggression are normalized in that there is pressure among boys to behave in sexually aggressive ways while girls are compelled to accommodate males' needs and desires (Hird \& Jackson, 2001; Tolman, Spencer, Rossen-Reynoso \& Porche, 2003).In married life, the woman is seen not as an individual but, rather as a representation of various opinions formed from experiences of battered relationships seen in the family in the form of maltreatment, sexual abuse and economic abuse. All these experiences create some form of fear and inhibit the woman from expressing herself without fear or let (Akintunde et al, 2002).

\section{Statement of the Problem}

http://escipub.com/american-journal-of-educational-research-and-reviews/ 
According to the FIDA-GHANA 2011, in recent times, domestic violence issues have persistently been the highest of cases presented to the Legal Aid Services Centre of FIDA-GHANA. Between 2010 and 2012, the centre recorded 347 cases bordering on domestic violence issues. Report from the Domestic Violence and Victim Support Unit (DOVVSU) of the Ghana Police Service Head Office in Accra also showed that the unit received 15,495 cases of battered women nation-wide. This shows that of all the forms of domestic violence, physical violence seems to be the predominant one.

Data obtained from the Winneba DOVVSU also showed that between 2010 and 2012, the unit received 1,465 cases of violence against women. In a chat with the officer in charge of DOVVSU, he intimated that in most cases females who called at the unit to report of violence cases were just interested in the police arresting the perpetrator and putting them in the cell overnight, that alone on the part of the victims was enough deterrence for the perpetrators. This was as a result that if they pursued the case up to the point of going to court to seek redress, society would ridicule them so in most instances the cases were later withdrawn. Nature of cases received included; indecent assault, non-maintenance, assault, causing unlawful damage, rape, unlawful ejection, causing harm and threatening. Out of the total number of 1,465 cases received, only 503 went to court, and even in these cases most of the females reluctantly gave witness and as a result some of them were considered as "foolish case". For the remaining 962, about 361 complainants failed to follow up on the case and 601 were withdrawn and settled at home. Also data obtained from the Effutu Municipal office of the Department of Social Welfare (DSW) between the same periods showed that 1,027 women suffered domestic violence in its various forms. Nature of cases received included non-maintenance, paternity dispute, neglect, family welfare, custody, forced ejection and refusal to perform customary marriage rites. Out of this number, 800 cases were handled at the DSW, 105 were later referred to the Family Tribunal for legal consideration and the remaining 122 failed to follow up on the case.

Though many pragmatic initiatives and policies have been put in place both nationally and internationally to fight against this menace, domestic violence is still being perpetuated against women. In Ghana for instance, the Domestic violence Bill (Act 732) was passed in the year 2007 in order to address the menace. This Act ensures that a victim is granted a protection order if they so wish, (section 12). However, in reality, the government or state has no shelter homes for victims to stay while their concerns are being addressed. Also, there are no counsellors attached to the Domestic Violence and Victim Support Unit of the Police Service to counsel victims as well as perpetrators of violence. Domestic Violence has become an endemic social problem in some African societies, including Ghana due to the way and manner women are perceived.

This research work wanted to find out the perception of respondents on domestic violence and also to suggest pragmatic strategies that could be put in place to reduce the incidence of domestic violence against women in the Effutu Municipality.

\section{Methodology \\ Research Design}

The study was a fact-finding exercise and the design used here was descriptive survey. According to Saranrakos (1998), descriptive surveys are versatile and practical, especially in their administration. It has been recommended for use in health and human performances, as well as in education, social, and behavioural sciences. Descriptive survey offers the researcher accurate descriptions of what people in the target population do and think. It also allows the researcher to present the findings with frequencies. 
Figure 1: Conceptual Framework for Domestic Violence

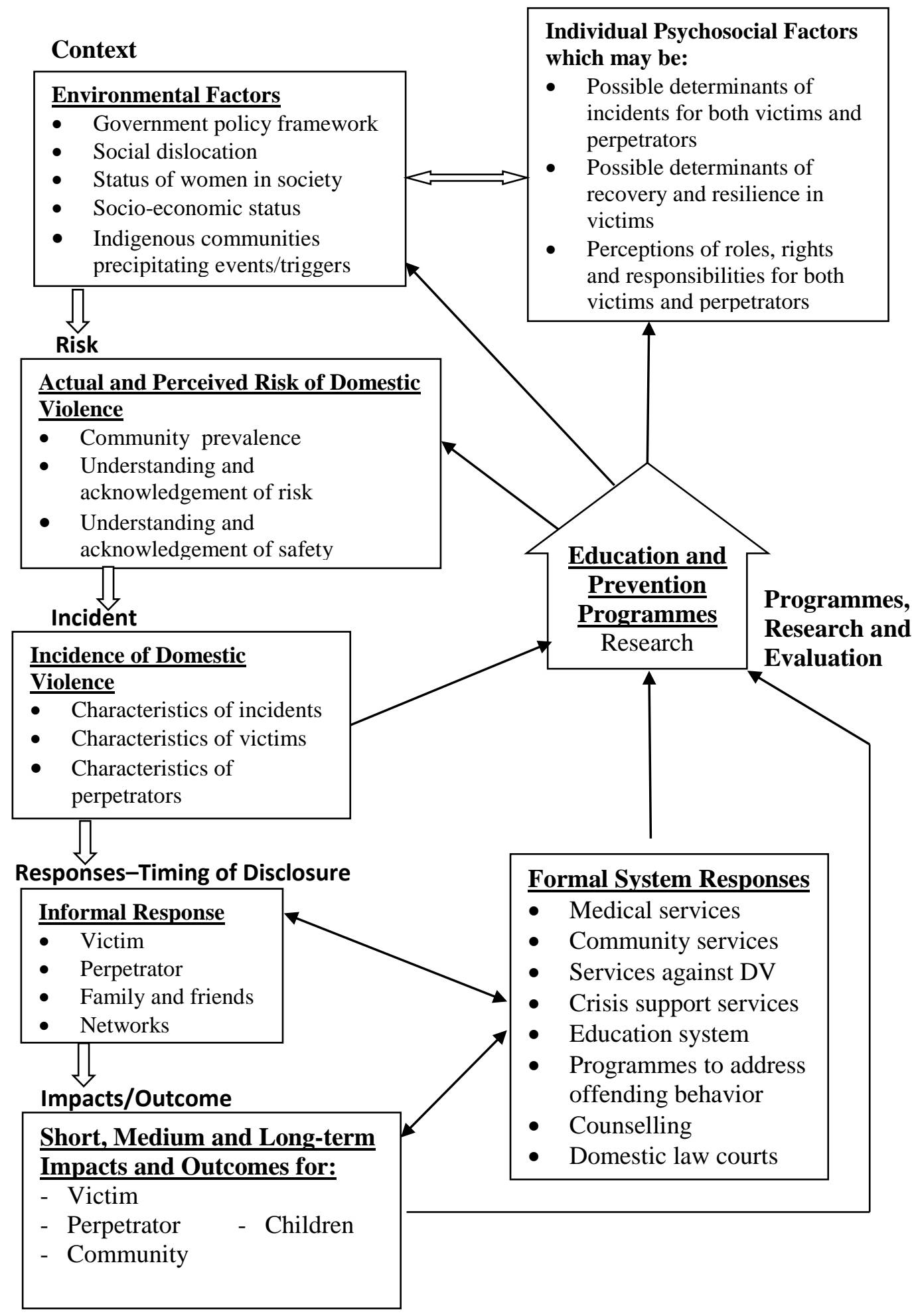

Adopted from Australian Bureau of Statistics, (2009) and modified by the researchers

Pittenger (2002) sees design as the process of making decisions before a situation arises in which the decision has to be carried out. Bryman (2001) also points out that there two major research designs for educational research. These are qualitative and quantitative designs.

Picciano (2004) sees quantitative design as a research design which involves the use of numerical values when collecting data. 
This research work made use of both designs and this brought about the mixed method. It was believed that by combining qualitative and quantitative methods, the researchers would broaden their horizon on domestic violence and boost the credibility of the findings of this research work.

\section{Research Instruments}

Two research instruments were used in data collection; a questionnaire and semi-structured interview guide. These enable the researchers to have wider range and an in-depth information from the respondents.

The questionnaire used for data collection covered five aspect of attitudes, constituting domestic violence such as physical abuse, sexual violence, Psychological or emotional abuse, economic violence and, Cultural and Life-Time Perception of Domestic Violence.

The scale includes statement covering important aspect of Domestic violence. The respondents were requested to express on a five-point likert-type scale, the extent of agreement or disagreement between the opinions expressed in each statement. Besides, respondents were asked to provide their Bio Data with regard to sex, age, marital status Educational qualification, religion, occupation and number of children.

A score of $5,4,3,2$ and 1 was given to the category of SA (Strongly Agree), A (Agree), Not Certain (NC), Disagree (D), and strongly disagree.

Based on this, the research instrument designed was first pre-tested in two communities within the Gomoa East District; Pomadze and Asebu as a means of ascertaining the reliability. The pre-test was conducted using fifty-four respondents. The measure of reliability using (Crombach's alpha) was 0.943

\section{Population}

The target population refers to the entire group of individuals or objects to which researchers are interested in generalizing the conclusions.
The accessible population usually has varying characteristics and it is also known as the theoretical population (Castillo 2009). The study area was Mburabam, community within the Effutu Municipality in the Central Region of Ghana and all males and females within the age range of 18 and 50 years constituted the population. The current estimated total population of Effutu Municipality stood at 68, 597 while that of Mburabam was 1,266 (Effutu Municipal Assembly Shared Growth and Development Plan, 2012-2015). The accessible population comprised all males and females aged between 18 and 50 years, male perpetrators and female victims, all resident at Mburabam, Winneba within the Effutu Municipality.

Officials from Department of Social Welfare (DSW), Commission on Human Rights and Administrative Justice (CHRAJ), Domestic Violence and Victim Support Unit (DOVVSU) and the magistrate court in Effutu Municipality were also part of the population.

\section{Sample}

According to Cohen (1995) a sample is a subset of a population selected as participants in an experiment. First, systematic sampling technique, which is a probability sampling technique, was used to select the sample population of 300 within Mburabam, Winneba Effutu Municipality for the quantitative aspect of the study. Hence a sample frame of five was drawn and used. This population comprised of males and females aged between 18 and 50 years of age. Secondly, a non-probability sampling technique, namely purposive sampling was used in selecting a sample size of 12 for the qualitative aspect of the study. The researcher used the purposive sampling for the qualitative aspect and as a result, she gained access to persons who have been involved directly with domestic violence.

The researchers interviewed 4 female victims of domestic violence and 4 perpetrators of domestic violence in the Effutu Municipality. The researcher also interviewed an Officer http://escipub.com/american-journal-of-educational-research-and-reviews/ 
each from DSW, DOVVSU, CHRAJ and the Magistrate/Judge at the Court. This brought the total sample size to 312 . Information accessed from DOVVSU and DSW showed that about $90 \%$ of domestic violence complaints received were lodged by illiterate females. Hence, the researcher believed that interviewing these women would help her in gaining insight into the reality on the ground without misrepresentation, since most of these females could neither read or write. Also discussing with them in their indigenous language made them feel at home and opened up for the discussion. By employing this strategy, the researcher gained relevant varied opinions as well as an in-depth understanding of domestic violence in totality. The rationale for choosing this number was to ensure that many diverse opinions were captured while an in-depth understanding was also gained on the subject matter.

\section{Sampling Procedure}

Sequential sampling procedure involves the drawing of multiple samples and administering them one after the other until cumulatively, they meet the objectives of the study (Lewis-Beck, Bryman and Liao, 2004).The researcher used the sequential approach of sampling. This was chosen in order to reach a broader segment of the target population which in turn brought about varied opinions that existed on the topic.

First, simple random sampling technique was used in selecting 300 respondents for the quantitative aspect of the study and then another 12 was selected for the qualitative part by using purposive sampling technique. Questionnaires and interview guide were utilised in fetching for information from the sample population.

\section{Data Collection Procedure}

The collection of data was done in three stages or phases. First, a letter of introduction was obtained from the Department of Psychology and Education. Before the community entry and distribution of questionnaires to individuals who were resident at Mburabam, Winneba in the Effutu Municipality. Copies of the letter were sent to the Domestic Violence and Victim Support Unit, (DOVVSU), the Ghana Police Service, Commission on Human Rights and Administrative Justice, (CHRAJ) and the Department of Social Welfare, (DSW) all in Effutu Municipality for the identification and location of victims of domestic violence.

After this, victims were selected based on purposive sampling technique and interviewed. Data were collected in two phases. First, questionnaires were distributed to 300 respondents to solicit for opinions; secondly, interviews were conducted with four victims of domestic violence, four perpetrators of domestic violence and officers from the already mentioned agencies.

A semi-structured interview guide was used for the interviews. This allowed participants an opportunity to move the conversation along. The researchers personally administered the questionnaires and conducted the interviews.

\section{Data Analysis Plan}

In analyzing the data obtained from the field, the researcher employed the use of the Statistical Package for the Social Sciences, (SPSS), which is a computerised programme used for statistical analysis. This assisted in coding and presenting responses in frequencies and tables. Both descriptive and inferential statistics were used to analyse the quantitative data.

Another tool that the researchers used was the Analysis of Variance, (ANOVA), which is a statistical method for examining differences between two or more means. In this study, the analysis of variance was used to investigate the differences in perception of respondents with regard to the themes developed based on their demographic characteristics such as age, educational background, marital status, religion, gender and number of children. By using this, the researchers were able to compare the means from the quantitative aspects of the 
research in order to determine the level of differences or otherwise in responses.

The type of analysis of variance employed was the one-way analysis of variance and was also used to test for the statistical significance of the differences in the perception of respondents based on demographic characteristics and draw conclusions from the data.

The researchers employed iteration reading and constant comparative analysis (Glaser 1965) in the analysis of the qualitative data. This helped the researchers to identify recurring topics which helped the researcher develop themes for the responses gathered from the field.

Iteration is act of repeating a process, either to generate on unbounded sequence of a outcomes, or with the aim of approaching a desired goal, target or result (Timperly, Wilson, Barrer \& Fung, 2007).

\section{Ethical Issues}

In conducting any research, it is important to consider ethical issues. Ethics in research refer to the considerations taken in order to respect and protect the rights of participants and other parties associated with the study, (Reynolds, 1992).

To apply this ethical underpinning, participants were informed of the purpose of the study, and then their consent was also sought before involving them. Care was also taken not to compel any participants into the study. Rather they were involved on their own volition. Participants were also assured of protection of their identity so that they remained anonymous.

\section{RESEARCH QUESTIONS}

Research Question one (1): What are peoples' perception about domestic violence against women in the Effutu Municipality?

This section presents the rated responses of respondents with regard to their perception of Domestic Violence against women in the Effutu municipality. The Likert scale developed was used to measure the strength of agreement or otherwise to items of physical abuse by http://escipub.com/american-journal-of-educational-research-and-reviews/
Husbands, Economic violence by husbands, cultural and life-time perception of domestic violence. The Likert scale of 1 to 5 representing strongly disagree (1), disagree (2), not certain (3), agree (4) and strongly agree (5) were used to rate respondents' level of agreement or disagreement with the given item under the various themes. The rating of not certain (3) was maintained because the researcher did not want to force respondents to choose an item but to allow for freedom of choice and the understanding of the themes developed.

The perceptions of the respondents are presented below.

\section{Table 1 shows the means of respondents on physical Abuse by Husbands}

Table 1 reveals that respondents indicated a major form of physical abuse employed by husband as husband slaps wife $(m=3.46$; $\mathrm{SD}=1.63$ ). This was followed husband threatens or attacks wife with knife or gun $(\mathrm{m}=3.36$, SD $=1.71)$; Husband throws something at wife out of anger $(m=3.31$; $\mathrm{SD}=1.46$ ); Husband hit wife with a fist or something that could harm her $(m=3.24, S D=$ 1.56); husband pushes or shoves wife out of anger $(m=3.24, S D=1.34)$; Husband pulls wife's hair $(m=3.23, S D=1.59)$; Husband Twist wife's hair $(m=3.20, S D=1.52)$ and Husband Chokes or burns wife on purpose $(\mathrm{M}=3.08, \mathrm{SD}=1.64)$.

The overall mean of respondents on physical abuse by husband is 3.27 . This compared with the overall means, it could be concluded that respondents perceived the major form of physical abuse in the Winneba Municipality as Husband slaps wife $(M=3.46, S D=1.63)$ with the highest percentage rate of $13.26 \%$ as constituting physical abuse by Husbands. In other words, even though the respondents were not certain about the themes and items that constituted physical abuse by husbands, the mean shows a strong inclination that "Husband slaps wife" with the highest mean of 3.46 with a 13.26 percentage response. 
Table 1: Means of Respondents on Physical Abuse by Husbands

\begin{tabular}{|c|c|c|c|c|}
\hline Item & $\mathrm{N}$ & Percentages \% & Mean & $\begin{array}{l}\text { Std. } \\
\text { Deviation }\end{array}$ \\
\hline 1. Husband slaps wife & 280 & 13.26 & 3.46 & 1.63 \\
\hline Husband threatens or attacks wife with knife or gun & 280 & 12.87 & 3.36 & 1.71 \\
\hline 3. Husband throws something at wife out of anger & 280 & 12.67 & 3.31 & 1.46 \\
\hline Husband hits wife a fist or something else that could harm her & 280 & 12.41 & 3.24 & 1.58 \\
\hline 5. Husband pushes or shoves wife out of anger & 280 & 12.39 & 3.24 & 1.34 \\
\hline 6. Husband pulls wife's hair & 280 & 12.36 & 3.23 & 1.59 \\
\hline 7. Husband twist wife's hair & 280 & 12.26 & 3.20 & 1.52 \\
\hline 8. Husband chokes or burns wife on purpose & 280 & 11.77 & 3.08 & 1.64 \\
\hline Total & & 100 & & \\
\hline Mean & & & 3.27 & \\
\hline
\end{tabular}

Table 2: Mean of Respondents on Sexual Violence by husband

\begin{tabular}{lllll}
\hline Item & $\mathrm{N}$ & $\begin{array}{l}\text { Percentages } \\
\%\end{array}$ & Mean & $\begin{array}{l}\text { Std. } \\
\text { Deviation }\end{array}$ \\
\hline $\begin{array}{l}\text { 1. Husband engages wife in a sexual act that she does not want } \\
\text { 2. Husband forces wife to have sex with him when she does not }\end{array}$ & $\begin{array}{l}280 \\
\text { Want }\end{array}$ & 21.31 & 3.57 & 3.40 \\
Want & 20.82 & 3.49 & 1.46 \\
$\begin{array}{l}\text { 3. Wife has sex with husband she does not want because she is } \\
\text { afraid of what the husband may do }\end{array}$ & 280 & 20.27 & 3.40 & 1.42 \\
4. Husband refuses to have sex with wife when she wants it & 280 & 19.08 & 3.20 & 1.29 \\
$\begin{array}{l}\text { 5. Wife cannot initiate sex with unless husband } \\
\text { Total }\end{array}$ & 280 & 18.52 & 3.10 & 1.34 \\
Mean & & 100 & & \\
\hline
\end{tabular}

Table 2 shows the means of Respondents on sexual violence by husband

Table 2 shows that respondents rate husband engages wife in a sexual act that she does not want $(n=280, m=3.57, S D=3.40)$ higher with $21.31 \%$. This was followed by husband forces wife to have sex with him when she does not want $(n=280, m=3.49, S D=1.46)$. On the part of women, respondents indicated that wife had sex with husband when she does not want because she is afraid of what the husband may do $(n=280 ; m=3.40, S D=1.42)$.

It can be deduced from the responses that the form of sexual violence perpetrated by husband was husbands engages wife in sexual act that she does not want. $(n=280 ; n=3.37 ; S D=3.40)$.

Table 3: Mean of Respondents on Psychological or emotional abuse by Husbands

\begin{tabular}{lllll}
\hline \multicolumn{1}{c}{ Item } & $\mathrm{N}$ & $\begin{array}{l}\text { Percentage } \\
\%\end{array}$ & Mean & $\begin{array}{l}\text { Std. } \\
\text { Deviation }\end{array}$ \\
\hline $\begin{array}{l}\text { 1. Husband always wants to know where the wife is } \\
\text { 2. Husband gets jealous when he sees wife talking or walking }\end{array}$ & 280 & 7.61 & 3.53 & 1.38 \\
with another man & & 7.53 & 3.49 & 1.36 \\
$\begin{array}{l}\text { 3. Husband refuses to talk to wife because she offended him } \\
\text { 4. Husband refuses to eat food prepared by wife }\end{array}$ & 279 & 7.49 & 3.48 & 1.32 \\
\end{tabular}


5. Husband does not allow wife to meet with friends

6. Wife cannot go out of the matrimonial home without informing husband first

7. Husband trivializes issues that are of great concern to the wife

8. Husband threatens to take children away from wife if she does not put up "appropriate" behavior

9. Husband limits the wife's contact with her relatives

10. Husband threatens to maim or kill wife if she decides to leave Her

11. Husband stalks or intimidate wife

12. Husband call $s$ wife names in a negative manner

13. Husband can go wherever he wants without informing wife

14. Husband chastises or embarrasses wife in public

Total

Mean
$280 \quad 7.46$

3.46

2.72

280

7.42

3.44

1.41

280

7.19

3.33

1.35

280

6.91

3.20

1.49

280

6.86

3.19

1.51

279

6.88

3.19

1.65

$\begin{array}{llll}280 & 6.82 & 3.16 & 1.56 \\ 280 & 6.81 & 3.16 & 2.41 \\ 280 & 6.80 & 3.15 & 1.54 \\ 280 & 6.74 & 3.13 & 1.65 \\ & 100 & & \end{array}$

3.31
Table 3 shows the mean score for the items of Psychological or emotional abuse by husband. The likert scale for items was scored and interpreted as follows. $1=$ strongly disagree, 2 $=$ Disagree $3=$ Not certain $4=$ Agree and $5=$ Strongly Agree. Respondents responded to fourteen items on what constituted Psychological abuse or emotional abuse by husbands.

Table 3 reveals that the mean of means of the respondent was 3.31. As mentioned in previous table since mean of the respondents was 3 , on a typical Likert scale, the respondents were not certain about the items which constituted
Psychological abuse. Since the mean of means is 3.31, items with average above 3.31 show a strong inclination as factors constituting perception on psychological abuse by husband. Therefore, the table indicates that item 1 (Husband always wants to know where the wife is). 2 (Husband gets jealous when he sees wife talking or walking with another man), 3 (Husband refuses to talk to wife because she offended him), 4 (Husband refuses to eat food prepared by wife) and 5(Husband does not allow wife to meet with friends had the highest mean scores of $3.53(\mathrm{SD}=1.38)$; $3.49(1.36)$; respectively.

\section{Table 4: Means of Respondents on Economic Violence by Husbands}

\begin{tabular}{lllll}
\hline Item & $\mathrm{N}$ & $\begin{array}{l}\text { Percentage } \\
\%\end{array}$ & Mean & $\begin{array}{l}\text { Std. } \\
\text { Deviation }\end{array}$ \\
\hline $\begin{array}{l}\text { 1. Husband refuses to provide money for up-keep of the } \\
\text { household }\end{array}$ & 280 & 21.19 & 3.35 & 1.57 \\
2. Husband refuses to provide for the children's education & 280 & 20.83 & 3.29 & 1.65 \\
$\begin{array}{l}\text { 3. Husband prevents wife from engaging any commercial activity } \\
\text { 4. Husband warns a trader not to sell items on credit to the wife }\end{array}$ & 280 & 20.13 & 3.18 & 1.48 \\
$\begin{array}{l}\text { 5. Husband does not give money for upkeep of the home } \\
\text { because he has provided trading capital for the wife }\end{array}$ & 280 & 19.45 & 3.07 & 1.33 \\
$\quad$ & & 100 & 2.91 & 1.55 \\
$\quad$ Total & & & 3.16 & \\
\hline
\end{tabular}


In Table 4, respondents responded to five (5) Again, since the average mean of the items on the theme, economic violence by respondents of items was 3.5, respondents Husbands. The table reveals that respondents rated item 1 (Husband refuses to provide money for upkeep of the household) higher ( $M=3.35$, $\mathrm{SD}=1.57$ ) as compared to item 5 (Husband does not give money for upkeep of the home because he has provided trading capital for the woman. In fact, respondent disagreed with item 5 (Husband does not give money for upkeep of the home because he has provided trading capital for the wife) with $\mathrm{m}=2.91 \mathrm{SD}=1.55$.

were uncertain of items as constituting economic violence by husband. The mean however gravitates toward item 1(Husband refuses to provide money for upkeep of the household with $\mathrm{m}=3.35, \mathrm{SD}=1.57$ as compared with mean of mean of 3.16 with the highest percentage of 21.19.

The Mean of Respondents on Cultural and LifeTime Perception of Domestic Violence is presented below.

\section{Table 5: Mean of Respondents on Cultural and Life-Time Perception of Domestic Violence}

\begin{tabular}{|c|c|c|c|c|}
\hline Item & No & $\begin{array}{l}\text { Percentages } \\
\%\end{array}$ & Mean & $\begin{array}{l}\text { Std. } \\
\text { Deviation }\end{array}$ \\
\hline $\begin{array}{l}\text { 1. The wife must seek approval from the husband before } \\
\text { accessing family planning services }\end{array}$ & 280 & 12.41 & 3.48 & 1.44 \\
\hline 2. The husband is superior to the wife & 280 & & 3.11 & 1.58 \\
\hline 3. The wife cannot visit relatives if the husband disagrees & 280 & 11.12 & 2.90 & 1.43 \\
\hline $\begin{array}{l}\text { 4. The wife becomes a property of the husband once dowry is } \\
\text { paid }\end{array}$ & 280 & 10.37 & 2.83 & 1.50 \\
\hline \multirow{2}{*}{$\begin{array}{l}\text { 5. The woman must not engage in any economic activity if the } \\
\text { husband is not in support of her decision to do so. }\end{array}$} & & 10.12 & & \\
\hline & 279 & 9.78 & 2.75 & 1.39 \\
\hline 8. The husband is justified to beat the wife if she disobeys him & 280 & 9.59 & 2.69 & 1.56 \\
\hline 7. The wife must not question the husband about his action & 280 & 9.49 & 2.66 & 1.50 \\
\hline $\begin{array}{l}\text { 8. It is all the fault of the woman when unwanted pregnancy } \\
\text { occurs }\end{array}$ & 280 & 9.34 & 2.61 & 1.56 \\
\hline \multirow{2}{*}{$\begin{array}{l}\text { 9. The husband does not need to seek opinion of the wife when } \\
\text { taking family decision }\end{array}$} & & & & 1.50 \\
\hline & 280 & 9.07 & 2.54 & 1.53 \\
\hline 10. The husband must not trust money with the wife & 279 & 8.70 & 2.44 & 1.37 \\
\hline Total & & 100 & & \\
\hline Mean & & & 2.80 & \\
\hline
\end{tabular}

Table 5 measured the rate of responses of respondents on the above theme. As indicated in the above table, response rate 1 (The wife must seek approval from the husband before accessing family planning services) high $(\mathrm{m}=3.48$, SD $1.44,12.41 \%)$ followed by 2 (The husband is superior to the wife $(11.12 \%$, $\mathrm{m}=3.11, \mathrm{SD}=1.52$ ). The above result also indicates that the respondents disagreed with items $3-10$ as the average score was in the range of 2.44-2.90. Mean of means by themes is shown below in Table 12

\section{Table 5: Mean of means by themes}

\begin{tabular}{ll}
\hline Theme & Mean Score \\
Sexual violence & 3.35 \\
\hline
\end{tabular}


Psychological or emotional abuse

Physical abuse

Economic violence

Cultural and Life-Time Perception of Domestic Violence

Mean
3.31

3.27

3.16

2.80

3.18
As could be seen from Table 6 , the overall averages of the above themes produced the following results: Sexual violence (3.35). Psychological or emotional abuse (3.31), physical abuse (3.27), economic violence (3.16) and Cultural and Life-time perception of domestic violence (2.80).

On a typical likert scale on which the scores are on a five-point scale- 1 being the lowest and 5 being the highest, a score of three implies an average score. Since all the means values obtained can be approximated to three, it means that the respondents were generally not certain about all the themes that were considered. However, the respondents disagreed with items of the theme on Cultural and Life-time perceptions of domestic violence.

Research Question Two (2): What is the difference between Demographic Characteristics and perception of Domestic Violence against Women in the Effutu Municipality.

\section{Justification for ANOVA for Likert scale variables}

According to Carifio and Perla (2007), one aim in the construction of a Likert scale is that the "distance" between each item category is "equivalent". Therefore, in a good Likert scale the possible answers are usually formulated symmetrically: 'strongly disagree", "disagree", "agree neither nor disagree", "agree", "agree strongly". A good Likert scale will present symmetry of categories and therefore, equidistant attributes will typically be more clearly observed or, at least, inferred. When a Likert scale is symmetric and equidistant it will behave more like an interval-level measurement and therefore, in practice, Likert scales are often viewed as an interval scale.
On the basis of the explanation above, an ANOVA test was conducted to find out how the perceptions of respondents on domestic violence issues differed by their religious beliefs, educational background and marital status. The results of the tests are discussed below:

\subsection{Religious background and perceptions on domestic violence}

The analysis of variance test conducted for the four themes with regard to Religious Background (Christianity, Islam, Traditional and other religions) and perception of domestic violence yielded the following results. The results provided a highest mean 3.37(Christianity and traditional) and lowest mean of 1.0 for other religious groups in respect of perception on sexual abuse. With regard to the descriptive statistics on physical abuse, the test produced a highest mean of 3.58(traditional religion) and lowest mean of 1.0 for other religions. Concerning perception on Cultural and life time perception of domestic violence, the results produced highest mean of 3.37 for respondents with traditional religious background and the lowest mean of 2.00 for respondents from other religions. Religions background and perception of domestic violence with regard to Economic Violence also produced a highest mean of 3.32(traditional religion) and the lowest mean of 1.00 for respondents with other religious affiliations.

On Physical or emotional abuse, the results produced the highest mean of 3.48 for respondents with Islamic religious background and the lowest mean of 1.00 for respondents with other religious affiliations.

To further test the mean differences, a one-way analysis of variance test was conducted at an 
alpha level of 0.05 . The result of the test is presented in table 13.

The ANOVA test in Table 7 shows that the respondents of difference religious backgrounds differed in their views on what constitutes psychological or emotional abuse by husbands.

Table 6: Religious background and perceptions on domestic violence - ANOVA

\begin{tabular}{|c|c|c|c|c|c|c|}
\hline \multicolumn{2}{|l|}{ Variable } & \multirow{2}{*}{$\begin{array}{l}\begin{array}{l}\text { Sum of } \\
\text { Squares }\end{array} \\
13.627\end{array}$} & \multirow{2}{*}{$\frac{\text { df }}{4}$} & \multirow{2}{*}{$\begin{array}{l}\text { Mean Square } \\
3.407\end{array}$} & \multirow{2}{*}{$\begin{array}{l}\mathbf{F} \\
1.702\end{array}$} & \multirow{2}{*}{$\begin{array}{l}\text { Sig. } \\
.150\end{array}$} \\
\hline Physical abuse & Between Groups & & & & & \\
\hline & Within Groups & 550.358 & 275 & 2.001 & & \\
\hline & Total & 563.986 & 279 & & & \\
\hline \multirow{3}{*}{$\begin{array}{l}\text { Psychological or emotional } \\
\text { abuse }\end{array}$} & emotional Between Groups & 11.007 & 4 & 2.752 & 2.588 & .037 \\
\hline & Within Groups & 292.389 & 275 & 1.063 & & \\
\hline & Total & 303.396 & 279 & & & \\
\hline \multirow[t]{3}{*}{ Economic violence } & Between Groups & 14.736 & 4 & 3.684 & 2.384 & .052 \\
\hline & Within Groups & 425.035 & 275 & 1.546 & & \\
\hline & Total & 439.771 & 279 & & & \\
\hline \multirow{3}{*}{$\begin{array}{l}\text { Cultural } \\
\text { perception } \\
\text { violence }\end{array}$} & lifetime Between Groups & 15.570 & 4 & 3.893 & 3.889 & .004 \\
\hline & domestic Within Groups & 275.273 & 275 & 1.001 & & \\
\hline & Total & 290.843 & 279 & & & \\
\hline \multirow[t]{3}{*}{ Sexual abuse } & Between Groups & 8.745 & 4 & 2.186 & 1.371 & .244 \\
\hline & Within Groups & 438.651 & 275 & 1.595 & & \\
\hline & Total & 447.396 & 279 & & & \\
\hline
\end{tabular}

Table 7 shows Religious background and perceptions on domestic violence - ANOVA

The test produced a significant $p$-value of 0.037 . Also, cultural and lifetime perceptions of domestic violence differed by the respondents' religious backgrounds. The $p$-value was 0.004 which is highly significant. However, respondents' views on physical abuse, economic abuse and sexual abuse did not differ by their religious backgrounds.

Post hoc analysis was conducted to determine differences in opinion with regard to religious background and perceptions on domestic violence issues. The result is as follows:

Cultural and lifetime perception of domestic violence:
The Tukey post-hoc test showed that Christians and Traditional among the respondents differed in their views on cultural and lifetime perception of domestic violence ( $p$-value $=0.034$ ).

\section{Educational level and perceptions on domestic Violence}

The analysis of variance test conducted for the four themes with regard to Educational Background (not educated, basic, secondary, tertiary and others) and perception of domestic violence yielded the following results. The results provided a highest mean 3.43(tertiary education) and lowest mean of 2.33 for others such as technical schools as NVTI in respect of perception on sexual abuse. With regard to the descriptive statistics on physical abuse, the test produced a highest mean of 3.50 (tertiary 
education) and lowest mean of 2.33 for others. Concerning perception on Cultural and life time perception of domestic violence, the results produced highest mean of 3.06 for respondents with basic education background and the lowest mean of 2.33 for respondents with other educational qualification such as NVTI. Educational Level and perception of domestic violence with regard to Economic Violence also produced a highest mean of 3.49 (not educated) and the lowest mean of 2.66 for respondents with secondary education.

On Physical or emotional abuse, the results produced the highest mean of 3.58 for respondents with basic education background and the lowest mean of 2.99 for respondents with secondary education.

To further test the mean differences, a one-way analysis of variance test was conducted at an alpha level of 0.05 . The result of the test is presented in table 8.
Table 8 below shows the Educational level and perceptions on domestic violence ANOVA

An ANOVA test was conducted to determine if respondents' educational background differed on their perceptions on domestic violence. The test results in Table 8 ( $p$-value of 0.566 ) shows that the respondents did not significantly differ in their views on what constitutes sexual violence by husbands irrespective of their educational background. However, they differed on their views on psychological or emotional abuse, economic violence, cultural and lifetime perception of domestic violence and physical abuse with p-values of $0.012,0.005,0.012$ and 0.025 respectively.

Post hoc analysis was conducted to determine differences in opinion with regard to educational level and perceptions on domestic violence issues.

Table 7: Educational level and perceptions on domestic violence - ANOVA

\begin{tabular}{|c|c|c|c|c|c|c|}
\hline \multicolumn{2}{|l|}{ Variable } & \multicolumn{2}{|l|}{ Sum of } & Mean Square & $\mathbf{F}$ & Sig. \\
\hline \multicolumn{2}{|c|}{ Psychological or emotional Between Groups } & 15.779 & 5 & 3.156 & \multirow[t]{3}{*}{3.006} & \multirow[t]{3}{*}{.012} \\
\hline abuse & Within Groups & 287.618 & 274 & 1.050 & & \\
\hline & Total & 303.396 & 279 & & & \\
\hline \multirow[t]{3}{*}{ Economic violence } & Between Groups & 26.108 & 5 & 5.222 & \multirow[t]{3}{*}{3.459} & \multirow[t]{3}{*}{.005} \\
\hline & Within Groups & 413.664 & 274 & 1.510 & & \\
\hline & Total & 439.771 & 279 & & & \\
\hline \multirow{3}{*}{$\begin{array}{l}\text { Cultural ar } \\
\text { perception } \\
\text { violence }\end{array}$} & lifetime Between Groups & 14.961 & 5 & 2.992 & \multirow[t]{3}{*}{2.972} & \multirow[t]{3}{*}{.012} \\
\hline & domestic Within Groups & 275.882 & 274 & 1.007 & & \\
\hline & Total & 290.843 & 279 & & & \\
\hline \multirow[t]{3}{*}{ Physical abuse } & Between Groups & 25.622 & 5 & 5.124 & \multirow[t]{3}{*}{2.608} & \multirow[t]{3}{*}{.025} \\
\hline & Within Groups & 538.364 & 274 & 1.965 & & \\
\hline & Total & 563.986 & 279 & & & \\
\hline \multirow[t]{3}{*}{ Sexual abuse } & Between Groups & 6.268 & 5 & 1.254 & \multirow[t]{3}{*}{.779} & \multirow[t]{3}{*}{.566} \\
\hline & Within Groups & 441.128 & 274 & 1.610 & & \\
\hline & Total & 447.396 & 279 & & & \\
\hline
\end{tabular}




\section{Psychological and emotional abuse:}

The Tukey post-hoc test result showed that respondents with basic and secondary education differed in their views on what constitutes psychological or emotional abuse by husbands $(p$-value $=0.011)$. Also, respondents with tertiary and secondary education differed in their views $p$-value $=0.023$

\section{Economic violence:}

Respondents who had no formal education had different views on what constitutes economic violence by husbands from those who had secondary education ( $p$-value $=0.008$ ). In addition, respondents who had basic education and secondary education differed in their views $(p$-value $=0.04)$ and those with tertiary and secondary education also differed in their views ( $p$-value $=0.01)$.

\section{Cultural and lifetime perception of domestic violence:}

The Tukey post-hoc test indicated that respondents with tertiary and basic education differed marginally in their views on cultural and lifetime perceptions of domestic violence $(p$ value $=0.06$ )

\section{Physical abuse:}

The test showed that respondents with tertiary and secondary education differed in their view on what constitutes physical abuse by husbands ( $p$-value $=0.024$ ).

\section{Marital status and perceptions on Domestic Violence}

The analysis of variance test conducted for the four themes with regard to Marital Status (Single, cohabitation, married, divorced and widowed) and perception of domestic violence yielded the following results. The results provided a highest mean 3.58(widowed) and lowest mean of 3.20 for married couple in respect of perception on sexual abuse. With regard to the descriptive statistics on physical abuse, the test produced a highest mean of 3.67(widowed) and lowest mean of 3.19 for married. Concerning perception on Cultural and life time perception of domestic violence, the results produced highest mean of 3.0 for respondents in a cohabitation relationship and the lowest mean of 2.84 for respondents who are single. Marital Status and perception of domestic violence with regard to Economic Violence also produced a highest mean of 3.75 for respondents widowed and the lowest mean of 3.03for respondents who are married.

On Physical or emotional abuse, the results produced the highest mean of $3.75 \mathrm{for}$ respondents widowed and the lowest mean of 3.21 for respondents in some cohabitation relationships.

To further test the mean differences, a one-way analysis of variance test was conducted at an alpha level of 0.05 . The result of the test is presented in Table 15.

Table 9 shows Marital Status and Perceptions on Domestic Violence - ANOVA

An ANOVA test to determine if respondents' marital status influences their perceptions on domestic violence issues shows that the respondents did not differ in their views for all the variables considered. The results shown in Table 9 produced $p$-values of $0.308,0.066$, $0.579,0.281$ and 0.144 for psychological or emotional abuse, economic violence, cultural and lifetime perception, physical abuse and sexual abuse respectively.

\section{Gender and perception of Domestic Violence}

The analysis of variance test conducted for the four themes with regard to Gender (Male and Female) and perception of domestic violence yielded the following results. The results provided a highest mean 3.36 for male and lowest mean of 3.32 for female in respect of perception on sexual abuse. With regard to the descriptive statistics on physical abuse, the test produced a highest mean of 3.34 for male and lowest mean of 3.24 for female. Concerning perception on Cultural and life time perception of domestic violence, the results produced highest mean of 2.89 for male gender and the lowest mean of 2.83 for female category; 
Gender and perception of domestic violence with regard to Economic Violence also produced a highest mean of 3.18 for male and the lowest mean of 3.16 for female.

On Physical or emotional abuse, the results produced the highest mean of 3.36 for female and the lowest mean of 3.30 for female.

To further test the mean differences, a one-way analysis of variance test was conducted at an alpha level of 0.05 . The result of the test is presented in table 10.
Table 10 shows the Gender Perception of domestic Violence (ANOVA)

An ANOVA test to determine if the gender of respondents influences their perceptions on domestic violence issues shows that the respondents did not differ in their views for all the variables considered. The results shown in Table 10 produced $p$-values of $0.683,0.942$, $0.484,0.548$ and 0.615 for psychological or emotional abuse, economic violence, cultural and lifetime perception, physical abuse and sexual abuse respectively.

Table 8: Marital Status and Perceptions on Domestic Violence - ANOVA

\begin{tabular}{|c|c|c|c|c|c|c|}
\hline \multicolumn{2}{|l|}{ Variable } & \multicolumn{2}{|l|}{ Sum of } & Mean Square & $\mathbf{F}$ & Sig. \\
\hline \multicolumn{2}{|c|}{ Psychological or emotional Between Groups } & 6.516 & 5 & 1.303 & \multirow[t]{3}{*}{1.203} & \multirow[t]{3}{*}{.308} \\
\hline & Within Groups & 296.881 & 274 & 1.084 & & \\
\hline & Total & 303.396 & 279 & & & \\
\hline \multirow[t]{3}{*}{ Economic violence } & Between Groups & 16.222 & 5 & 3.244 & \multirow[t]{3}{*}{2.099} & \multirow[t]{3}{*}{.066} \\
\hline & Within Groups & 423.549 & 274 & 1.546 & & \\
\hline & Total & 439.771 & 279 & & & \\
\hline \multirow{3}{*}{$\begin{array}{l}\text { Cultural and } \\
\text { perception of } \\
\text { violence }\end{array}$} & lifetime Between Groups & 3.983 & 5 & .797 & \multirow[t]{3}{*}{.761} & \multirow[t]{3}{*}{.579} \\
\hline & domestıc Within Groups & 286.860 & 274 & 1.047 & & \\
\hline & Total & 290.843 & 279 & & & \\
\hline \multirow[t]{3}{*}{ Physical abuse } & Between Groups & 12.676 & 5 & 2.535 & \multirow[t]{3}{*}{1.260} & \multirow[t]{3}{*}{.281} \\
\hline & Within Groups & 551.309 & 274 & 2.012 & & \\
\hline & Total & 563.986 & 279 & & & \\
\hline \multirow[t]{3}{*}{ Sexual abuse } & Between Groups & 13.169 & 5 & 2.634 & \multirow[t]{3}{*}{1.662} & \multirow[t]{3}{*}{.144} \\
\hline & Within Groups & 434.228 & 274 & 1.585 & & \\
\hline & Total & 447.396 & 279 & & & \\
\hline
\end{tabular}

Table 9: Gender Perception of domestic Violence (ANOVA)

\begin{tabular}{|c|c|c|c|c|c|c|}
\hline & & Sum of Squares & Df & Mean Square & $\mathrm{F}$ & Sig. \\
\hline \multirow[t]{3}{*}{ Physical or emotional abuse } & Between Groups & .833 & 2 & .417 & .381 & .683 \\
\hline & Within Groups & 302.563 & 277 & 1.092 & & \\
\hline & Total & 303.396 & 279 & & & \\
\hline \multirow[t]{3}{*}{ Economic violence } & Between Groups & .190 & 2 & .095 & .060 & .942 \\
\hline & Within Groups & 439.582 & 277 & 1.587 & & \\
\hline & Total & 439.771 & 279 & & & \\
\hline Cultural & lifetimeBetween Groups & 1.520 & 2 & .760 & .728 & .484 \\
\hline
\end{tabular}




$\begin{array}{lllllr}\text { perception of } & \text { domesticWithin Groups } & 289.323 & 277 & 1.044 \\ \text { violence } & \text { Total } & 290.843 & 279 & & \\ \text { Physical abuse } & \text { Between Groups } & 2.442 & 2 & 1.221 & .602 \\ & \text { Within Groups } & 561.544 & 277 & 2.027 & .548 \\ & \text { Total } & 563.986 & 279 & & .488 \\ \text { Sexual abuse } & \text { Between Groups } & 1.570 & 2 & .785 & 1.609 \\ & \text { Within Groups } & 445.827 & 277 & & \end{array}$

\section{Age and Perception of Domestic Violence}

The analysis of variance test conducted for the four themes with regard to age and perception of domestic violence yielded the following results. The results provided a mean range of 3.59 and 3.19 for the age groups between 30 40 years and 20-30 years respectively in respect of perception on sexual abuse. With regard to the descriptive statistics on physical abuse, the test produced a mean between 3.60 and 3.06. The highest mean of 3.60 was associated with the age group between 30-40 years and the lowest concerned the group less than 20 years. Concerning perception on Cultural and life time perception of domestic violence, the results produced highest mean of 2.90 associated with the age group between 30-40 years and the lowest mean of 2.79 with regard to the age group less than 20 years; age and perception of domestic violence with regard to Economic Violence also produced a highest mean of 3.29 associated with the age group between 30-40 years and the lowest mean of 3.08 for the age group 40-50 years.

On Physical or emotional abuse, the results produced the highest mean of 3.39 for the age group between 30-40 years and the lowest mean of 3.18 associated with the age group below 20 years.

To further test the mean differences, a one-way analysis of variance test was conducted at an alpha level of 0.05 . The result of the test is presented in table 17.

Age and Perception of Domestic ViolenceAnalysis of Variance (ANOVA) is shown in table 11 below

The test produced a significant $p$-value of 0.047 indicating that respondent differed in their opinion on domestic violence in relation physical abuse. However, respondents' views on, psychological or emotional abuse, economic abuse and sexual abuse did not differ by their age with p-values of $0.821,0.830$, $0.844,0.208$ respectively.

Table 10: Age and Perception of Domestic Violence-Analysis of Variance (ANOVA)

\begin{tabular}{lllllll}
\hline & & Sum of & & & & Sig. \\
\hline Physical or emotional abuse & Between Groups & 1.677 & 4 & .419 & .382 & .821 \\
& Within Groups & 301.719 & 275 & 1.097 & & \\
& Total & 303.396 & 279 & & & \\
Economic violence & Between Groups & 2.352 & 4 & .588 & .370 & .830 \\
& Within Groups & 437.420 & 275 & 1.591 & & \\
\multirow{2}{*}{$\begin{array}{l}\text { Cultural and lifetime } \\
\text { of domestic violence }\end{array}$} & Total & 439.771 & 279 & & & \\
& Within Groups & 289.369 & 275 & 1.052 & & \\
& Total & 290.843 & 279 & & &
\end{tabular}




$\begin{array}{lllllr}\text { Physical abuse } & \text { Between Groups } & 19.318 & 4 & 4.830 & 2.438 \\ & \text { Within Groups } & 544.667 & 275 & 1.981 & .047 \\ \text { Sexual abuse } & \text { Total } & 563.986 & 279 & & .208 \\ & \text { Between Groups } & 9.437 & 4 & 2.359 & 1.481 \\ & \text { Within Groups } & 437.960 & 275 & 1.593 & \\ & \text { Total } & 447.396 & 279 & & \end{array}$

Occupation and Perception of Domestic Violence

The analysis of variance test conducted for the four themes with regard to Occupation (Formal Sector, informal Sector, Students and unemployed) and perception of domestic violence yielded the following results. The results provided a highest mean 3.42 for respondents in the formal sector and lowest mean of 3.25 for respondents who were unemployed. With regard to the descriptive statistics on physical abuse, the test produced a highest mean of 3.47 for respondents in the formal sector and lowest mean of 3.18 for students. Concerning perception on Cultural and life time perception of domestic violence, the results produced highest mean of 3.25 for respondents unemployed for male gender and the lowest mean of 2.88 for respondents who were students. Occupation and perception of domestic violence with regard to Economic Violence also produced a highest mean of 4.0 for respondents unemployed and the lowest mean of 3.11 for respondents who were students.

On Physical or emotional abuse, the results produced the highest mean of 3.75 for respondents were unemployed for female and the lowest mean of 3.25 for students.

To further test the mean differences, a one-way analysis of variance test was conducted at an alpha level of 0.05 . The result of the test is presented in table 12.

\section{Table 12 below shows the Occupation and Perception of Domestic Violence-(ANOVA)}

An ANOVA test to determine if respondents' occupation influences their perceptions on domestic violence issues shows that the respondents did not differ in their views for all the variables considered. The results shown in Table 12 produced $p$-values of $0.523,0.083$, $0.080,0.053$ and 0.056 for psychological or emotional abuse, economic violence, cultural and lifetime perception, physical abuse and sexual abuse respectively.

Table 11: Occupation and Perception of Domestic Violence-(ANOVA)

\begin{tabular}{lllllll}
\hline & & Sum of & & & \\
& & Squares & Df & Mean Square & F & Sig. \\
\hline Physical or emotional abuse & Between Groups & 3.510 & 4 & .878 & .805 & .523 \\
& Within Groups & 299.886 & 275 & 1.090 & & \\
& Total & 303.396 & 279 & & & \\
Economic violence & Between Groups & 12.935 & 4 & 2.234 & 2.083 & .083 \\
& Within Groups & 426.836 & 275 & 1.552 & & \\
Cultural and lifetime perception & Total & 439.771 & 279 & & & \\
of domestic violence & Within Groups & 282.190 & 275 & 1.026 & & \\
& Total & 290.843 & 279 & & & \\
Physical abuse & Between Groups & 18.822 & 4 & 4.706 & 2.108 & .053 \\
& Within Groups & 545.164 & 275 & 1.982 & & \\
\hline
\end{tabular}




Total $\quad 563.986 \quad 279$

Sexual abuse

$\begin{array}{llll}\text { Between Groups } & 5.348 & 4 & 1.337 \\ \text { Within Groups } & 442.048 & 275 & 1.607 \\ \text { Total } & 447.396 & 279 & \end{array}$

Table 13 below shows Correlation of Gender

Research Question three (3): What is the and perception of Domestic Violence

relationship between participants' demographic factors and perception of Domestic Violence in the Effutu Municipality.

Perceptions with respect to cases of Domestic Violence play an important role in shaping the social environment in which the issue occur. The researcher therefore inquired if relationship existed with regard to people's perceptions of domestic violence in the municipality.

Correlation coefficient was utilised to obtain the relationship between the demographic characteristics of the participants and their perception of Domestic violence against Women in the Effutu Municipality. Relevant correlates on the subjective norms (i.e. perception of others approval) are presented in Tables 13-19.

The relationship between Gender and perception of domestic violence against women were examined and the results presented in table 19 below:

Table 13 shows the cross tabulation of the result indicating the distribution of categories between Gender and Domestic Violence. The inspection of the numerical value of the correlation coefficient indicates that there was a very weak negative relationship between Gender and perception of domestic violence in the Effutu Municipality ( $r=-.042$, degree of freedom $=277, p=.484)$. Hence, the test statistic indicated no significant correlation between gender and perception of Domestic Violence. Therefore, the null hypothesis which states that there is no statistically significant relation between Demographic characteristics (Gender) is hereby retained/accepted. This shows that both males and females have the same perception towards domestic violence. As men perceived differences, same do women.

The relationship between Occupation and perception of domestic violence against women were examined and the results presented in table 14 below:

Table 12: Correlation of Gender and perception of Domestic Violence

\begin{tabular}{|c|c|c|c|}
\hline & & Gender & TDV \\
\hline \multirow[t]{6}{*}{ Gender } & \multirow{2}{*}{$\begin{array}{l}\text { Pearson Correlation Sig. (2- } \\
\text { tailed) }\end{array}$} & 1 & -.042 \\
\hline & & & .484 \\
\hline & \multirow{2}{*}{$\begin{array}{l}\text { Sum of Squares and Cross- } \\
\text { products Covariance }\end{array}$} & & \\
\hline & & 80.111 & -230.112 \\
\hline & \multirow{2}{*}{$\mathrm{N}$} & .287 & -.834 \\
\hline & & 280 & 277 \\
\hline \multirow[t]{6}{*}{ TDV } & \multirow{2}{*}{$\begin{array}{l}\text { Pearson Correlation Sig. (2- } \\
\text { tailed) }\end{array}$} & -.042 & 1 \\
\hline & & .484 & \\
\hline & \multirow{2}{*}{$\begin{array}{l}\text { Sum of Squares and Cross- } \\
\text { products Covariance }\end{array}$} & & \\
\hline & & -230.112 & 3.7335 \\
\hline & \multirow{2}{*}{ 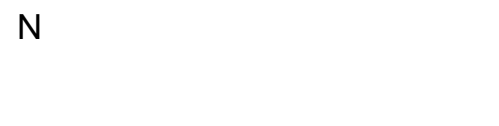 } & -.834 & 1.3533 \\
\hline & & 277 & 277 \\
\hline
\end{tabular}

TDV-Total Domestic Violence 
Table 13: Correlation of Occupation and perception of Domestic Violence

\begin{tabular}{|c|c|c|c|}
\hline & & Occupation & TDV \\
\hline \multirow[t]{6}{*}{ TDV } & \multirow{2}{*}{$\begin{array}{llll}\begin{array}{l}\text { Pearson } \\
\text { tailed) }\end{array} & \text { Correlation } & \text { Sig. } & \text { (2- } \\
\end{array}$} & \multirow[t]{3}{*}{1} & .060 \\
\hline & & & \multirow{2}{*}{.318} \\
\hline & \multirow{2}{*}{$\begin{array}{l}\text { Sum of Squares and Cross- } \\
\text { products Covariance }\end{array}$} & & \\
\hline & & 3.7335 & 529.356 \\
\hline & \multirow[t]{2}{*}{$\mathrm{N}$} & 1.3533 & 1.918 \\
\hline & & 277 & 277 \\
\hline \multirow[t]{6}{*}{ Occupation } & \multirow{2}{*}{$\begin{array}{l}\text { Pearson Correlation Sig. (2- } \\
\text { tailed) }\end{array}$} & .060 & 1 \\
\hline & & .318 & \\
\hline & \multirow[t]{2}{*}{$\begin{array}{l}\text { Sum of Squares and Cross- } \\
\text { products Covariance }\end{array}$} & & \\
\hline & & 529.356 & 3.7335 \\
\hline & \multirow{2}{*}{$\mathrm{N}$} & 1.918 & 1.3533 \\
\hline & & 277 & 277 \\
\hline
\end{tabular}

TDV-Total Domestic Violence

Table 14 shows the Correlation of $p>0.05$ ). Therefore, the null hypothesis that Occupation and perception of Domestic there is no statistically significant relationship Violence between Demographic Characteristics Table 14 shows the cross tabulation of the result indicating the distribution of categories between Occupation and Domestic Violence. The inspection of the numerical value of the correlation coefficient indicates that there was a strong positive correlation between Occupation and perception of domestic violence in the Effutu municipality ( $r=.060$, degree of freedom $=277, \quad p=.318$ ) but the test yielded no statistically significant relationship $(r=.060$, table 15 below:

Table 14: Correlation of Religion and perception of Domestic Violence

\begin{tabular}{|c|c|c|c|}
\hline & & Religion & TDV \\
\hline \multirow[t]{6}{*}{ TDV } & \multirow{2}{*}{$\begin{array}{l}\text { Pearson Correlation Sig. } \quad \text { (2- } \\
\text { tailed) }\end{array}$} & \multirow[t]{3}{*}{1} & -.049 \\
\hline & & & \multirow[t]{2}{*}{.416} \\
\hline & \multirow{2}{*}{$\begin{array}{l}\text { Sum of Squares and Cross- } \\
\text { products Covariance }\end{array}$} & & \\
\hline & & 3.7335 & -328.224 \\
\hline & \multirow{2}{*}{$\mathrm{N}$} & 1.3533 & -1.189 \\
\hline & & 277 & 277 \\
\hline \multirow[t]{5}{*}{ Religion } & \multirow{2}{*}{$\begin{array}{l}\text { Pearson Correlation Sig. }(2- \\
\text { tailed) }\end{array}$} & -.049 & 1 \\
\hline & & .416 & \\
\hline & $\begin{array}{l}\text { Sum of Squares and Cross- } \\
\text { products Covariance }\end{array}$ & & \\
\hline & \multirow{2}{*}{$\mathrm{N}$} & -328.224 & 119.768 \\
\hline & & -1.189 & .429 \\
\hline
\end{tabular}


TDV-Total Domestic Violence

Table 15 below shows the Correlation of Religion and perception of Domestic Violence

Table 15 shows the cross tabulation of the result indicating the distribution of categories between Religion and perception of Domestic Violence. The inspection of the numerical value of the correlation coefficient indicates that there was a very weak but negative correlation between Religion and perception of domestic violence in the Effutu Municipality ( $r=-.049$, degree of freedom $=277, p=.416$ ) but the test yielded no statistically significant relationship between Religion and perception of domestic violence $(r=-.049, p>0.05)$. This result indicates that the claim of no correlation is supported by the results. This shows that respondents expressed the same view irrespective of one's religious background.

The relationship between Educational Qualification and perception of domestic violence against women were examined and the results presented in table 16 below:

Table 15: Correlation of Educational Qualification and perception of Domestic Violence

\begin{tabular}{|c|c|c|c|}
\hline & & $\begin{array}{l}\text { Educational } \\
\text { Qualification }\end{array}$ & TDV \\
\hline \multirow[t]{6}{*}{ TDV } & \multirow{2}{*}{$\begin{array}{llll}\text { Pearson } & \text { Correlation } & \text { Sig. } & (2- \\
\text { tailed) }\end{array}$} & \multirow[t]{3}{*}{1} & $\begin{array}{l}.099 \\
\end{array}$ \\
\hline & & & \multirow[t]{2}{*}{.100} \\
\hline & \multirow{2}{*}{$\begin{array}{l}\text { Sum of Squares and Cross- } \\
\text { products Covariance }\end{array}$} & & \\
\hline & & 3.1335 & -1215.274 \\
\hline & \multirow{2}{*}{$\mathrm{N}$} & 1.3533 & -4.403 \\
\hline & & 277 & 277 \\
\hline \multirow[t]{5}{*}{ Educational qualification } & \multirow{2}{*}{$\begin{array}{l}\text { Pearson Correlation Sig. } \quad \text { (2- } \\
\text { tailed) }\end{array}$} & -.099 & \multirow[t]{2}{*}{1} \\
\hline & & .100 & \\
\hline & $\begin{array}{l}\text { Sum of Squares and Cross- } \\
\text { products Covariance }\end{array}$ & 1215271 & 406568 \\
\hline & \multirow[t]{2}{*}{$\mathrm{N}$} & -4.403 & 1.457 \\
\hline & & 277 & 280 \\
\hline
\end{tabular}

TDV-Total Domestic Violence

Table 16 shows the Correlation of Educational Qualification and perception of Domestic Violence

Table 16 shows the cross tabulation of the result indicating the distribution of categories between Educational Qualification and perception of Domestic Violence. The inspection of the numerical value of the correlation coefficient indicates a strong or high negative correlation between one's educational background and perception of domestic violence in the Effutu municipality $(r=-0.99$, degree of freedom $=277, p=.100$ ) but the test yielded no significant relationship between Educational background and perception of domestic violence $(r=-.099, p>0.05)$. This result indicates that the claim of no correlation between one's Educational background and perception of domestic violence is supported by the results. The results indicate that respondents with basic, secondary and tertiary 
education background expressed the same against women were examined and the results view point on domestic violence. presented in table 17 below:

The relationship between the Number of

Children and perception of domestic violence

Table 16: Correlation of Number of Children and perception of Domestic Violence

\begin{tabular}{|c|c|c|c|}
\hline & & Number of Children & TDV \\
\hline \multirow[t]{6}{*}{ TDV } & \multirow{2}{*}{$\begin{array}{llll}\begin{array}{l}\text { Pearson } \\
\text { tailed) }\end{array} & \text { Correlation Sig. } & \text { (2- } \\
\end{array}$} & \multirow[t]{3}{*}{1} & .089 \\
\hline & & & \multirow[t]{2}{*}{.138} \\
\hline & $\begin{array}{l}\text { Sum of Squares and Cross- } \\
\text { products Covariance }\end{array}$ & & \\
\hline & & 3.7335 & 1775.700 \\
\hline & & 1.3533 & 6.434 \\
\hline & & 277 & 277 \\
\hline \multirow[t]{6}{*}{ Number of children } & \multirow{2}{*}{$\begin{array}{l}\text { Pearson Correlation Sig. } \quad \text { (2- } \\
\text { tailed) }\end{array}$} & .089 & 1 \\
\hline & & .138 & \\
\hline & $\begin{array}{l}\text { Sum of Squares and Cross- } \\
\text { products Covariance }\end{array}$ & & \\
\hline & \multirow[t]{3}{*}{ 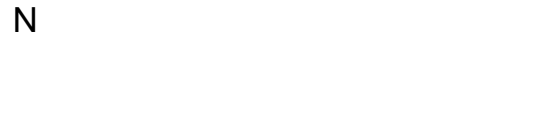 } & 1775.700 & 1062.271 \\
\hline & & 6.434 & 3.807 \\
\hline & & 277 & 280 \\
\hline
\end{tabular}

TDV-Total Domestic Violence

Table 17 shows the Correlation of Number of Children and perception of Domestic Violence

Table 17 shows the cross tabulation of the result indicating the distribution of categories between Number of children and perception of Domestic Violence. The inspection of the numerical value of the correlation coefficient indicates a strong or high positive correlation between the number of children a person has and perception of domestic violence in the
Effutu municipality $(r=0.89$, degree of freedom $=277, p=.138$ ) but the test yielded no statistically significant relationship ( $r=.089$, $p>0.05)$. This result indicates that the claim of no correlation between number of children and perception of domestic violence is supported by the results.

The relationship between Age and perception of domestic violence against women were examined and the results presented in table 18 below:

Table 17: Correlation of Age and perception of Domestic Violence

\begin{tabular}{|c|c|c|c|}
\hline & & Age & TDV \\
\hline \multirow[t]{6}{*}{ TDV } & \multirow{2}{*}{$\begin{array}{l}\text { Pearson Correlation Sig. } \quad(2- \\
\text { tailed) }\end{array}$} & \multirow[t]{3}{*}{1} & -.014 \\
\hline & & & \multirow[t]{2}{*}{.820} \\
\hline & \multirow[t]{2}{*}{$\begin{array}{l}\text { Sum of Squares and Cross- } \\
\text { products Covariance }\end{array}$} & & \\
\hline & & 3.7335 & -140.635 \\
\hline & \multirow{2}{*}{$\mathrm{N}$} & 1.3533 & -.510 \\
\hline & & 277 & 277 \\
\hline \multirow[t]{3}{*}{ Age } & \multirow{2}{*}{$\begin{array}{l}\text { Pearson } \\
\text { tailed) }\end{array}$} & -.014 & \multirow[t]{3}{*}{1} \\
\hline & & .820 & \\
\hline & \multicolumn{2}{|l|}{ Sum of Squares and Cross- } & \\
\hline
\end{tabular}


TDV-Total Domestic Violence

Table 18 below shows the Correlation of Age and perception of Domestic Violence

Table 18 shows the cross tabulation of the result indicating the distribution of categories between Age and perception of Domestic Violence. The inspection of the numerical value of the correlation coefficient indicates a very weak but negative correlation between the number of children a person has and perception of domestic violence in the Effutu municipality $(r=-.014$, degree of freedom $=277$, $\mathrm{p}=.820$ ) but the test yielded no statistically significant relationship between age and perception of domestic violence $(r=-.014$, $p>0.05)$. This result indicates that the claim of no correlation between Age and perception of domestic violence is supported by the results. This suggests that that age of respondents and their views on domestic violence were the same.

The relationship between Marital Status and perception of domestic violence against women were examined and the results presented in table 19 below:

Correlation of Marital Status and perception of Domestic Violence is shown in table 19 below.

Table 18: Correlation of Marital Status and perception of Domestic Violence

\begin{tabular}{|c|c|c|c|}
\hline & & Marital Status & TDV \\
\hline \multirow[t]{5}{*}{ TDV } & Pearson Correlation Sig. (2-tailed) & 1 & -.012 \\
\hline & $\begin{array}{l}\text { Sum of Squares and Cross- } \\
\text { products Covariance }\end{array}$ & & .836 \\
\hline & $\mathrm{N}$ & 3.7335 & -161.718 \\
\hline & & 1.3533 & -.586 \\
\hline & & 277 & 277 \\
\hline \multirow[t]{5}{*}{ Marital Status } & Pearson Correlation Sig. (2-tailed) & -.012 & 1 \\
\hline & $\begin{array}{l}\text { Sum of Squares and Cross- } \\
\text { products Covariance }\end{array}$ & .836 & \\
\hline & $\mathrm{N}$ & -161.718 & 451.943 \\
\hline & & -.586 & 1.620 \\
\hline & & 277 & 280 \\
\hline
\end{tabular}

TDV-Total Domestic Violence

Table 19 shows the cross tabulation of the result indicating the distribution of categories between Marital status and perception of Domestic Violence. The inspection of the numerical value of the correlation coefficient indicates a very weak but negative relationship between marital status and perception of domestic violence in the Effutu Municipality ( $r=-$ .012 , degree of freedom $=277, p=.836$ ) but the test yielded no statistically significant relationship between age and perception of domestic violence $(r=-.012, p>0.05)$. This result indicates that the claim of no correlation between Marital Status and perception of 
domestic violence is supported by the results. This suggests that views expressed by married, divorced, cohabitation relationships were the same.

The inspection of the correlation coefficient yielded clear evidence of the strength of the relationship between the demographic characteristics and perception of domestic violence. The results yielded a very weak negative relationship between Gender, Religion, Age and marital status and perception of domestic violence; a strong positive relationship between Occupation, number of Children, a strong but negative relationship between Education and perception of Domestic Violence.

\subsection{Testing of Hypotheses}

Much statistical analysis hinges on the notion of Statistical significance. This section examined the hypotheses generated in the study. The hypotheses concerned were the test of statistical significances of differences and relationships or associations between the demographic characteristics of respondents and their perception of Domestic violence in the Effutu Municipality. Kirk (1999) indicates that a statistically significance results is one for which chance is an unlikely explanation and as such the certainty and the confidence of must be established. To this end, the following hypotheses were formulated:

\section{Hypothesis 1}

$\mathrm{H}_{\mathrm{OA}}$ : there is no statistically significant correlation between demographic characteristic (Gender, age, marital status, religion, Educational Qualification) of respondent and perception of domestic violence.

$\mathrm{H}_{1 \mathrm{~A}}$ : there is a statistically significant relationship between demographic characteristic (Gender, age, marital status, religion, Educational Qualification) of respondent and perception of domestic violence.

Table 19: Correlation of Gender and perception of Domestic Violence

\begin{tabular}{|c|c|c|c|}
\hline & & Gender & TDV \\
\hline \multirow[t]{6}{*}{ Gender } & \multirow{2}{*}{$\begin{array}{l}\text { Pearson Correlation Sig. (2- } \\
\text { tailed) }\end{array}$} & \multirow[t]{2}{*}{1} & -.042 \\
\hline & & & .484 \\
\hline & \multirow{2}{*}{$\begin{array}{l}\text { Sum of Squares and Cross- } \\
\text { products Covariance }\end{array}$} & & \\
\hline & & 80.111 & -230.112 \\
\hline & \multirow{2}{*}{$\mathrm{N}$} & .287 & -.834 \\
\hline & & 280 & 277 \\
\hline \multirow[t]{6}{*}{ TDV } & \multirow{2}{*}{$\begin{array}{l}\text { Pearson Correlation Sig. (2- } \\
\text { tailed) }\end{array}$} & -.042 & 1 \\
\hline & & .484 & \\
\hline & $\begin{array}{l}\text { Sum of Squares and Cross- } \\
\text { products Covariance }\end{array}$ & & \\
\hline & \multirow{3}{*}{$\mathrm{N}$} & -230.112 & 3.7335 \\
\hline & & -.834 & 1.3533 \\
\hline & & 277 & 277 \\
\hline
\end{tabular}

Table 20 below shows Correlation of Gender and perception of Domestic Violence

Table 20 shows the cross tabulation of the result indicating the distribution of categories between Gender and Domestic Violence. The inspection of the numerical value of the correlation coefficient indicates that there was a very weak correlation between Gender and perception of domestic violence in the Effutu http://escipub.com/american-journal-of-educational-research-and-reviews/ 
Municipality $(r=-.042$, degree of freedom $=277$, perception of domestic violence $(r=-.042$, $\mathrm{p}=.484$ ) but the test yielded no statistically $\mathrm{p}>0.05$ ). This result indicates that the claim of significant relationship between Gender and no correlation is supported by the results.

Table 20: Correlation of Occupation and perception of Domestic Violence

\begin{tabular}{|c|c|c|c|}
\hline & & Occupation & TDV \\
\hline \multirow[t]{6}{*}{ TDV } & \multirow{2}{*}{$\begin{array}{l}\text { Pearson Correlation Sig. } \\
\text { tailed) }\end{array}$} & \multirow[t]{3}{*}{1} & .060 \\
\hline & & & \multirow[t]{2}{*}{.318} \\
\hline & $\begin{array}{l}\text { Sum of Squares and Cross- } \\
\text { products Covariance }\end{array}$ & & \\
\hline & \multirow{3}{*}{$\mathrm{N}$} & 3.7335 & 529.356 \\
\hline & & 1.3533 & 1.918 \\
\hline & & 277 & 277 \\
\hline \multirow[t]{6}{*}{ Occupation } & \multirow{2}{*}{$\begin{array}{l}\text { Pearson Correlation Sig. } \quad \text { (2- } \\
\text { tailed) }\end{array}$} & .060 & 1 \\
\hline & & .318 & \\
\hline & $\begin{array}{l}\text { Sum of Squares and Cross- } \\
\text { products Covariance }\end{array}$ & & \\
\hline & \multirow{3}{*}{ 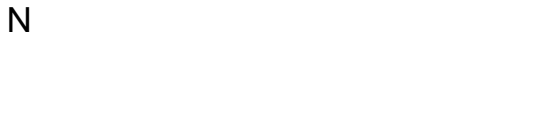 } & 529.356 & 3.7335 \\
\hline & & 1.918 & 1.3533 \\
\hline & & 277 & 277 \\
\hline
\end{tabular}

Table 21 shows the Correlation of violence in the Effutu municipality $(r=0.60$, Occupation and perception of Domestic degree of freedom $=277, p=.318$ ) but the test Violence

Table 21 shows the cross tabulation of the result indicating the distribution of categories between Occupation and Domestic Violence. The inspection of the numerical value of the correlation coefficient indicates that there was a strong positive significant correlation between yielded no statistically significant relationship or association between Occupation and perception of domestic violence $(r=.060$, $p>0.05$ ). By this result, we therefore fail to reject the hypothesis of no correlation between Occupation and perception of Domestic Violence.

Occupation and perception of domestic

Table 21: Correlation of Religion and perception of Domestic Violence

\begin{tabular}{|c|c|c|c|}
\hline & & Religion & TDV \\
\hline \multirow[t]{6}{*}{ TDV } & \multirow{2}{*}{$\begin{array}{l}\text { Pearson Correlation Sig. } \\
\text { tailed) }\end{array}$} & \multirow[t]{3}{*}{1} & $\begin{array}{l}-.049 \\
\end{array}$ \\
\hline & & & \multirow[t]{2}{*}{.416} \\
\hline & $\begin{array}{l}\text { Sum of Squares and Cross- } \\
\text { products Covariance }\end{array}$ & & \\
\hline & \multirow{3}{*}{$\mathrm{N}$} & 3.7335 & -328.224 \\
\hline & & 1.3533 & -1.189 \\
\hline & & 277 & 277 \\
\hline \multirow[t]{6}{*}{ Religion } & \multirow{2}{*}{$\begin{array}{l}\text { Pearson Correlation Sig. }(2- \\
\text { tailed) }\end{array}$} & -.049 & 1 \\
\hline & & .416 & \\
\hline & $\begin{array}{l}\text { Sum of Squares and Cross- } \\
\text { products Covariance }\end{array}$ & & \\
\hline & \multirow{3}{*}{ 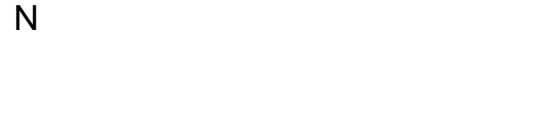 } & -328.224 & 119.768 \\
\hline & & -1.189 & .429 \\
\hline & & 277 & 280 \\
\hline
\end{tabular}


Table 22 below shows Correlation of Occupation and perception of Domestic Violence

Table 22 shows the cross tabulation of the result indicating the distribution of categories between Religion and perception of Domestic Violence. The inspection of the numerical value of the correlation coefficient indicates that there was a weak but significant negative correlation or association between Religion and perception of domestic violence in the Effutu Municipality $(r=-.049$, degree of freedom $=277, p=.416)$ but the test yielded no statistically significant relationship or association between Religion and perception of domestic violence $(r=-.049$, $p>0.05)$. by this result, we therefore fail to reject the claim of no correlation with regard to Religion and perception of Domestic Violence.

Table 23 shows the Correlation of Educational Qualification and perception of Domestic Violence

\begin{tabular}{|c|c|c|c|}
\hline & & $\begin{array}{l}\text { Educational } \\
\text { Qualification }\end{array}$ & TDV \\
\hline \multirow[t]{5}{*}{ TDV } & $\begin{array}{l}\text { Pearson Correlation Sig. } \quad \text { (2- } \\
\text { tailed) }\end{array}$ & \multirow[t]{2}{*}{1} & $\begin{array}{c}-.099 \\
100\end{array}$ \\
\hline & $\begin{array}{l}\text { Sum of Squares and Cross- } \\
\text { products Covariance }\end{array}$ & & .100 \\
\hline & \multirow{3}{*}{$\mathrm{N}$} & 3.7335 & -1215.274 \\
\hline & & 1.3533 & -4.403 \\
\hline & & 277 & 277 \\
\hline \multirow[t]{5}{*}{ Educational qualification } & \multirow{2}{*}{$\begin{array}{l}\text { Pearson Correlation Sig. (2- } \\
\text { tailed) }\end{array}$} & -.099 & \multirow[t]{2}{*}{1} \\
\hline & & .100 & \\
\hline & $\begin{array}{l}\text { Sum of Squares and Cross- } \\
\text { products Covariance }\end{array}$ & -1215274 & 406.568 \\
\hline & \multirow[t]{2}{*}{$\mathrm{N}$} & -4.403 & 1.457 \\
\hline & & 277 & 280 \\
\hline
\end{tabular}

Table 22: Correlation of Educational Qualification and perception of Domestic Violence

Table 23 shows the cross tabulation of the result indicating the distribution of categories between Educational Qualification and perception of Domestic Violence. The inspection of the numerical value of the correlation coefficient indicates a strong or high positive significant correlation or association between Educational one's educational background and perception of domestic violence in the Effutu municipality $(r=-0.99$, degree of freedom $=277, p=.100$ ) but the test yielded no statistically significant relationship between Educational background and perception of domestic violence ( $r=.099$, $p>0.05$ ). We therefore fail to reject the claim of no correlation between the variables.

Table 23: Correlation of Number of Children and perception of Domestic Violence

\begin{tabular}{llll}
\hline TDV & & Number of children & TDV \\
\hline $\begin{array}{l}\text { Pearson Correlation } \\
\text { tailed }\end{array}$ & Sig. $(2-1$ & .089 \\
Sum of Squares and Cross- & .138 \\
products Covariance & \multicolumn{2}{l}{3.7335} & 1775.700
\end{tabular}




\begin{tabular}{|c|c|c|c|}
\hline & $\mathrm{N}$ & 1.3533 & 6.434 \\
\hline & & 277 & 277 \\
\hline \multirow[t]{6}{*}{ Number of children } & Correlation Sig. (2- & .089 & 1 \\
\hline & tailed) & .138 & \\
\hline & $\begin{array}{l}\text { Sum of Squares and Cross- } \\
\text { products Covariance }\end{array}$ & & \\
\hline & $\mathrm{N}$ & 1775.700 & 1062.271 \\
\hline & IV & 6.434 & 3.807 \\
\hline & & 277 & 280 \\
\hline
\end{tabular}

Table 24 shows the Correlation of Number of Children and perception of Domestic Violence

Table 24 shows the cross tabulation of the result indicating the distribution of categories between Number of children and perception of Domestic Violence. The inspection of the numerical value of the correlation coefficient indicates a strong or high positive significant correlation or association between the number of children a person has and perception of domestic violence in the Effutu municipality $(r=0.89$, degree of freedom $=277, p=.138)$ but the test yielded no statistically significant relationship ( $r=.089, p>0.05)$. we therefore fail to reject the claim of no correlation between number of children and perception of domestic violence.

Table 24: Correlation of Age and perception of Domestic Violence

\begin{tabular}{|c|c|c|c|}
\hline & & Age & TDV \\
\hline \multirow[t]{6}{*}{ TDV } & \multirow{2}{*}{$\begin{array}{llll}\begin{array}{l}\text { Pearson } \\
\text { tailed) }\end{array} & \text { Correlation Sig. } & \text { (2- } \\
\end{array}$} & \multirow[t]{3}{*}{1} & -.014 \\
\hline & & & .820 \\
\hline & \multirow{2}{*}{$\begin{array}{l}\text { Sum of Squares and Cross- } \\
\text { products Covariance }\end{array}$} & & \\
\hline & & 3.7335 & -140.635 \\
\hline & \multirow[t]{2}{*}{$\mathrm{N}$} & 1.3533 & -.510 \\
\hline & & 277 & 277 \\
\hline \multirow[t]{6}{*}{ Age } & \multirow{2}{*}{$\begin{array}{l}\text { Pearson Correlation Sig. }(2- \\
\text { tailed) }\end{array}$} & -.014 & 1 \\
\hline & & .820 & \\
\hline & $\begin{array}{l}\text { Sum of Squares and Cross- } \\
\text { products Covariance }\end{array}$ & & \\
\hline & \multirow{3}{*}{ 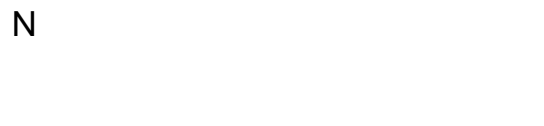 } & -140.635 & 280.111 \\
\hline & & -.510 & 1.004 \\
\hline & & 277 & 280 \\
\hline
\end{tabular}

Table 25 below shows Correlation of Age and perception of Domestic Violence

Table 25 shows the cross tabulation of the result indicating the distribution of categories between Age and perception of Domestic Violence. The inspection of the numerical value of the correlation coefficient indicates a negatively very weak correlation between Age and perception of domestic violence in the Effutu municipality $(r=-.014$, degree of freedom
$=277, p=.820$ ) but the test yielded no statistically significant relationship or association between age and perception of domestic violence $(r=-.014, \quad p>0.05)$. We therefore fail to reject the claim of no relationship between the variables.

Table 26 below shows Correlation of Marital Status and perception of Domestic Violence Table 26 shows the cross tabulation of the result indicating the distribution of categories 
between Marital status and perception of the Effutu municipality ( $r=-.012$, degree of Domestic Violence. The inspection of the freedom $=277, \mathrm{p}=.836$ ) but the test yielded no numerical value of the correlation coefficient statistically significant relationship or indicates a negatively weak but significant association between age and perception of correlation or association between marital domestic violence $(r=-.014, p>0.05)$. The result status and perception of domestic violence in indicates that the null hypothesis is supported.

Table 25: Correlation of Marital Status and perception of Domestic Violence

\begin{tabular}{|c|c|c|c|}
\hline & & Marital Status & TDV \\
\hline \multirow[t]{5}{*}{ TDV } & Pearson Correlation Sig. (2-tailed) & 1 & -.012 \\
\hline & $\begin{array}{l}\text { Sum of Squares and Cross- } \\
\text { products Covariance }\end{array}$ & & .836 \\
\hline & $\mathrm{N}$ & 3.7335 & -161.718 \\
\hline & & 1.3533 & -.586 \\
\hline & & 277 & 277 \\
\hline \multirow[t]{5}{*}{ Marital Status } & Pearson Correlation Sig. (2-tailed) & -.012 & 1 \\
\hline & $\begin{array}{l}\text { Sum of Squares and Cross- } \\
\text { products Covariance }\end{array}$ & .836 & \\
\hline & $\mathrm{N}$ & -161.718 & 451.943 \\
\hline & & -.586 & 1.620 \\
\hline & & 277 & 280 \\
\hline
\end{tabular}

\subsection{Hypothesis}

Нов: there is no statistically significant difference between demographic characteristic (religious background, Educational level, Marital Status, Gender, and Age) and perception of Domestic Violence.

$\mathrm{H}_{1 \mathrm{~B}}$ : there is statistically significant difference between demographic characteristic (religious background, Educational level, Marital Status,
Gender and Age) and perception of Domestic Violence

In order to support or not to support the hypothesis stated above, ANOVA test was carried to find out if responses regarding one's demographic characteristics differed from their perception of domestic violence at alpha level of 0.05 . The result of the test is presented in table

Table 26: Demographic Characteristics and Perception of Domestic Violence-Analysis of Variance (ANOVA)

\begin{tabular}{lllllll}
\hline & & \multicolumn{2}{l}{ Sum of Squares Df } & Mean Square & \multicolumn{2}{c}{ Sig. } \\
\hline Religious Background & Between Groups & 15140.485 & 4 & 3785.121 & 2.874 & .023 \\
& Within Groups & 385187.074 & 272 & 1316.864 & & \\
& Total & 373327.560 & 276 & & & \\
Occupation & Between Groups & 8974.329 & 4 & 2243.582 & 1.675 & .156 \\
& Within Groups & 364353.230 & 272 & 1339.534 & & \\
Educational Qualification & Total & 373327.560 & 276 & & & \\
& Between Groups & 13952.748 & 5 & 2790.550 & 2.104 & .065
\end{tabular}




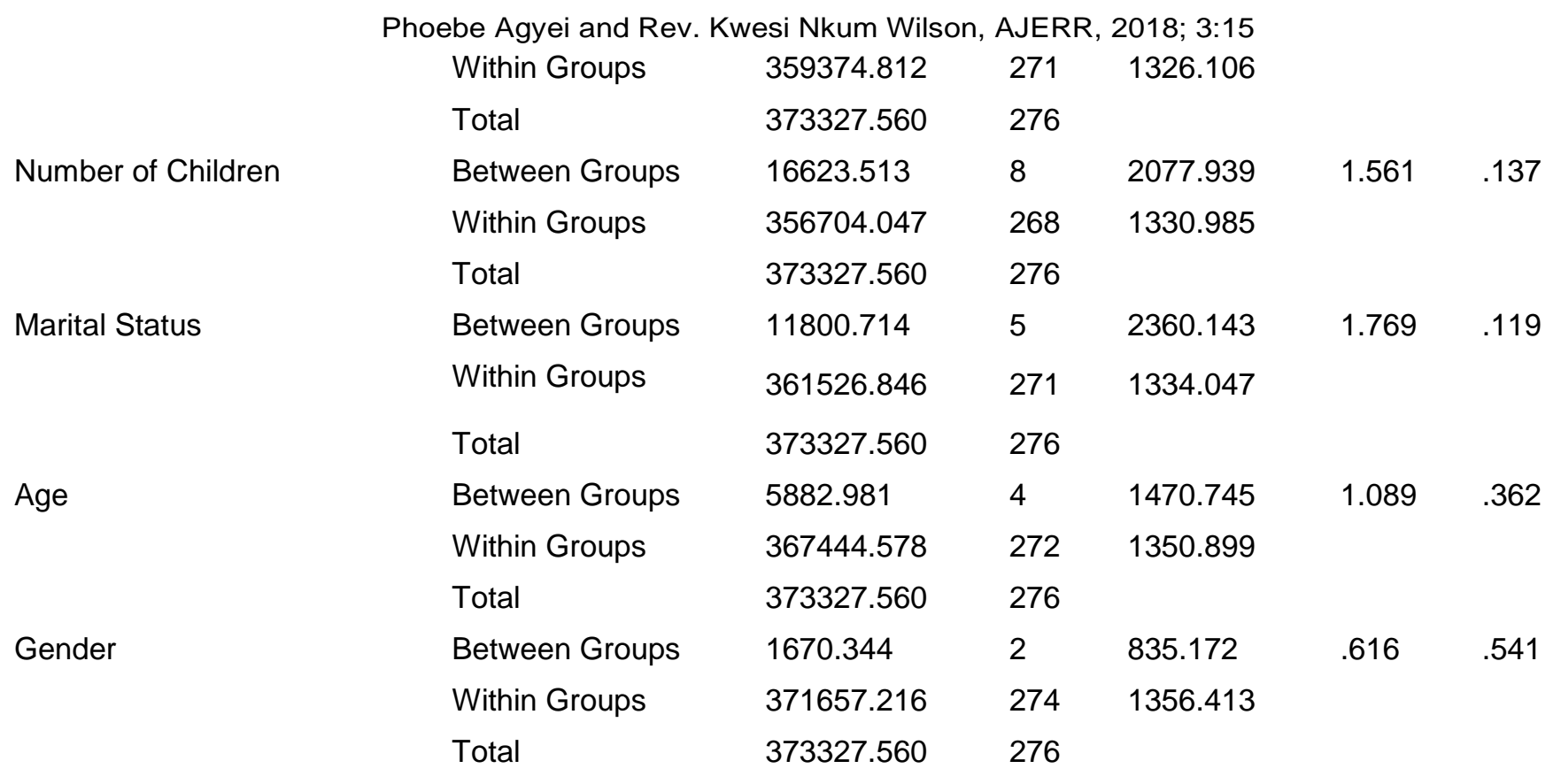

Table 27 below shows the Demographic Characteristics and Perception of Domestic Violence-Analysis of Variance (ANOVA)

The Analysis of variance results shown in Table 36 produced $p$ value of 0.023 for religious background and perception of domestic violence. The results indicate a statistically significant difference with regard to religious background and perception of domestic violence $(F=2.874, p=.023<\alpha=.05)$. Therefore, the null hypothesis that there is no statistical significance between religion and domestic violence is not supported. Hence there are statistical differences in the opinions expressed. Views expressed by respondents from Christian, Islam, Traditional and other religions were distinct from each other in respect to their views of domestic violence.

The results also produced $p$-values of 0.156 , $0.137,0.119,0.362$, and 0.541 for Occupation, Educational background, number of children, marital status, age and gender respectively but indicate statistically insignificant differences. The result indicates that the null hypothesis that there is no statistically significant difference between demographic characteristic (Occupation, Educational background, number of children, marital status, age and Gender) is supported. Hence views expressed by the groups were the same irrespective of their
Occupation, education, marital status, gender, age and number of children.

\section{Discussions}

\section{Perception on Domestic Violence}

Research question one investigated peoples' perceptions about domestic violence against women in the Effutu Municipality. Several findings are derived from the study in relation to the themes generated. The perception of respondents to each item on the theme were analysed using, simple percentages means and standard deviations. The findings are presented on tables 7 to 12 . The average mean of the respondents was 3.5 for all items constituting economic violence, Physical abuse, sexual violence, emotional abuse and items 1 and 2 of the characteristics of the cultural and life time perception of domestic violence. This means that in all, the respondents were uncertain about the themes and items generated as constituting domestic violence in the Effutu Municipality. This finding portrays the definitional problems with regard to uncertainty about what constitutes domestic violence. Reid (2000) observed that the definition of who can be involved in domestic violence incidents is changing, she argued: The seriousness of domestic violence is beyond question, but the extent of the problem is difficult to define, primarily because of the lack of agreement on a 
definition as well as the refusal of victims to report incidents of domestic violence. The finding is also consistent with the view of the Minister for Gender, Children and Social Protection who said that the Domestic Violence Act did not really tackle the issue of Psychological violence and this poses problem the issue crops up. She went on to say that though the law has been enabled to protect continue to stay in abusive relationships because the Ghanaian society has not wholly understood the problem that domestic violence brings to its victims as well as the larger society (Talking Point, Ghana Television, $15^{\text {th }}$ December, 2013).

However, the respondents disagreed with the items of the theme on culture and Life-time perception of domestic violence with average mean of 2.80 .

\subsubsection{Differences in perception of Domestic Violence}

The second objectives and its associated research question sought to investigate the extent to which demographic characteristics differed with regard to the perception of domestic violence in the Effutu Municipality. Participants' demographic characteristics were analysed using one-way analysis of variance to test for significant differences on perceptions of domestic violence. The findings are presented on tables 13 to 18.

\section{Religious Background}

The findings as shown in table 13 show significant differences in opinion with regard to psychological or emotional abuse $(p=.037)$, Cultural and Life-time perception $(\mathrm{p}=.004)$ and barely significant for Economic violence $(p=.052)$. But no significant differences in opinion existed for Physical abuse $(p=.150)$ and sexual abuse $(p=.244)$. The post hoc-analysis showed that Christians and Traditional religious background differed in their perceptions on domestic violence $(p=.034)$.

The findings also show that the younger a woman, is, the more she is to approve of domestic violence against wives and also women with lower education were more likely to approve of domestic violence as compared to those who have acquired higher education. Additionally, most traditional women were more likely to approve of domestic violence against women in comparison with women from Christian background.

\section{Educational Background}

In the analysis of variance test shown in table 14 , the respondents did not significantly differ on what constitute sexual violence $(p=.566)$. They however differ on their views on emotional abuse $(p=.012)$; economic violence $(p=.005)$, Culture and Life-Time $(p=.012)$ and Physical abuse $(p=.025)$. Post hoc analysis result showed that respondents with basic and secondary education differed in their views on what constitutes psychological or emotional abuse by husbands ( $p$-value $=0.011$ ). Also, respondents with tertiary and secondary education differed in their views $p$-value $=$ 0.023. Respondents who had no formal education had different views on what constitutes economic violence by husbands from those who had secondary education ( $p$ value $=0.008$ ). In addition, respondents who had basic education and secondary education differed in their views ( $p$-value $=0.04$ ) and those with tertiary and secondary education also differed in their views $(p$-value $=0.01)$. Also, respondents with tertiary and basic education differed marginally in their views on cultural and lifetime perceptions of domestic violence $(p$-value $=0.06)$ and respondents with tertiary and secondary education differed in their view on what constitutes physical abuse by husbands ( $p$-value $=0.024$ ). The findings confirm Oyediran, and Isiugo-Abanihe, (2003).

\section{Marital Status}

An ANOVA test to determine if respondents' marital status influences their perceptions on domestic violence issues shows that the respondents did not differ in their views for all the variables considered. The results shown in Table 15 produced $p$-values of $0.308,0.066$, 
$0.579,0.281$ and 0.144 for psychological or emotional abuse, economic violence, cultural and lifetime perception, physical abuse and sexual abuse respectively.

\section{Gender of Respondent}

An ANOVA test to determine if the gender of respondents influences their perceptions on domestic violence issues shows that the respondents did not differ in their views for all the variables considered. The results shown in Table 16 produced $p$-values of $0.683,0.942$, $0.484,0.548$ and 0.615 for psychological or emotional abuse, economic violence, cultural and lifetime perception, physical abuse and sexual abuse respectively.

\section{Age}

The test produced a significant $p$-value of 0.047 indicating that respondent differed in their opinion on domestic violence in relation physical abuse. However, respondents' views on, psychological or emotional abuse, economic abuse and sexual abuse did not differ by their age with $p$-values of $0.821,0.830$, $0.844,0.208$ respectively.

\section{Occupation}

An ANOVA test to determine if respondents' occupation influences their perceptions on domestic violence issues shows that the respondents did not differ in their views for all the variables considered. The results shown in Table 18 produced $p$-values of $0.523,0.083$, $0.080,0.053$ and 0.056 for psychological or emotional abuse, economic violence, cultural and lifetime perception, physical abuse and sexual abuse respectively.

\subsubsection{Correlation of Demographic characteristics and perception of Domestic Violence}

Research question three investigated the associations between the demographic characteristics and perception of domestic violence. The purpose of this analysis was to ascertain which of the characteristics would be useful in individual or group predictions of interventions for the addressing domestic violence issues in the Effutu Municipality.

The inspection of the numerical value of the correlation coefficient indicates that there was a very weak negative relationship between Gender and perception of domestic violence $(r=-$ .042 , degree of freedom $=277, p=.484$ ); a strong positive correlation between Occupation and perception of domestic violence $(r=.060$, degree of freedom $=277, p=.318$ ); a very weak but negative correlation between Religion and perception of domestic violence $(r=-.049$, degree of freedom $=277, \mathrm{p}=.416$ ); ; strong or high negative correlation between one's educational background and perception of domestic violence $(r=-0.99$, degree of freedom $=277, \mathrm{p}=.100) ; \mathrm{a}$ strong or high positive correlation between the number of children a person has and perception of domestic violence $(r=0.89$, degree of freedom $=277, p=.138) ; a$ very weak but negative relationship between marital status and perception of domestic violence $(r=-.012$, degree of freedom $=277$, $\mathrm{p}=.836$ )

The inspection of the correlation coefficient yielded clear evidence of the strength of the relationship between the demographic characteristics and perception of domestic violence. The results yielded a very weak negative relationship between Gender, Religion, Age and marital status and perception of domestic violence; a strong positive relationship between Occupation, number of Children, a strong but negative relationship between Education and perception of Domestic Violence.

The findings of the current study suggest that effort at addressing issues arising out of cases of domestic violence should be based on educational background, number of children and the occupation of the people in the Effutu Municipality.

\subsubsection{Mechanisms and/or Intervention to address incidence of Domestic Violence in the Effutu Municipality.}


Research question four aimed at an inquiry into mechanisms and interventions for addressing domestic violence issues in relation to the provision of counselling and law enforcement in relation to Officers attitude toward domestic violence in the Effutu municipality. Several findings were derived from the study. On the part of the Officers who handled domestic violence cases, there were adequate provision was made for the counselling of victims. However, they were divided in their opinions about this activity. Perpetrators and victims expressed contrary view stating that no counselling services was provided them though desired. Also on the effectiveness of the domestic violence Act at reducing the incidence of domestic violence, the study revealed that the effectiveness was punctuated with interference from family members and traditional authorities. Moreover, Victims and perpetrators expressed dissatisfaction on the way law enforcement Officers handles cases as in most cases they were threatened, refuse to arrest, blamed them and often insulted. There was also the attitude of non-reporting of cases as a result of the attitude of Officers. Studies has shown that many victims fail to report domestic violence issues to law enforcement agencies because of their perception that the Police are unwilling or unable to act on their behalf. (Traden \& Thoennes, 2000). These findings corroborate many studies. Professionals interviewed in the Elliott and Shanahan survey defined a wide range of behaviours, including psychological, emotional or verbal abuse, social abuse, economic abuse, and sexual abuse as violence. This might lead one to expect practical support for victims from professionals. However, research reveals quite a different picture. For example, in a number of Australian surveys, a high percentage (one-half or more) of victims have reported dissatisfaction with police interventions in spouse assault cases (Crancher et al., 1981, 1983; Victorian Department of the Premier \& Cabinet, 1985; Women's Information
Switchboard, 1980; Law Reform Commission, 1986; Egger \& Crancher, 1982; Hatty, 1985; Reed, 1982; Scutt, 1983). Victims related that police were reluctant to get involved; failed to arrest the batterer; often did not give referrals or gave misleading legal advice; often appeared to uncritically accept the assailant's version of events; frequently took a lengthy time to appear and then left quickly; appeared indifferent and even hostile; and seemed to trivialize the violence. Only Healy's (1984) research found victim satisfaction with police $(80 \%)$. The findings of the study corroborate what a District Court Judge in Ghana said in an interview conducted in Georgetown University Law Centre on March 13, 2014: "We hate to put men in jail. They provide maintenance. The cycle of poverty and lack of opportunity is vicious. We must be circumspect in dealing with such cases" (International Human Rights Clinic, 2003, p.17). These findings have implications for training and education for officers that handle domestic violence cases.

\section{Conclusions}

The following conclusions were made as a result of the findings of the study:

In general, the respondents were uncertain about the themes on sexual abuse, psychological or emotional abuse, physical abuse and economic violence on that were considered. However, the respondents disagreed with items constituting cultural and Life-time perception of domestic violence.

Perception on domestic violence differed with Demographic characteristic such as age, gender, marital status, number of children, educational background and religious background. With regard to religious background, Christians and Traditional people differed in their view on cultural and life-time perception about domestic violence against women in the Effutu Municipality. Views on domestic violence also differed with educational level of respondents. The study revealed that respondents with basic, secondary and tertiary education differed in their view of what http://escipub.com/american-journal-of-educational-research-and-reviews/ 
constituted psychological or emotional abuse; respondents with no formal education deferred in their view on economic violence. Additionally, respondents who had basic education, secondary education and tertiary education differed in their views on economic violence. Again, respondents with tertiary and basic education differed marginally in their view on cultural and life time perception of domestic violence. Moreover, respondents with tertiary education and secondary education differed in their view on what constituted physical abuse by husbands. Respondents' views on domestic violence did not differ with regard to their marital status, gender, occupation and age. The study revealed that there was a statistical significance differences with regard to religious background and perception of domestic violence in the Effutu Municipality. Hence the views expressed by respondents from Christian, Islam, traditional and others were distinct from each other in respect to the views expressed. The result also indicated no statistical differences with regard to occupation, education, number of children, gender and age. Views expressed by the group were the same.

Furthermore, the study had shown that there was a weak relationship between gender, religion, age and marital status and perception of domestic violence; a strong positive relationship between occupation, number of children and a strong but negative relationship educational level and perception of domestic violence. However, the test statistics yielded no statistical significance between the demographic characteristics and perception of domestic violence. This means that the respondents view expressed were the same irrespective of the demographic characteristics (education, age, marital status, gender, religion and occupation.)

There were institutions that offer services to reduce or forestall the incidence of domestic violence. However, both victims and perpetuators do not receive any counselling in any form. Victims and perpetrators expressed dissatisfaction with the way law enforcement agencies handled cases.

Lastly, domestic violence can result in marriage break ups, waywardness among children, children dropping out of school, frustration among marriage mates, injuries and trauma.

\section{Recommendations}

In order to curtail the menace of domestic violence, the following recommendations are made.

1. The state should incorporate into the school curriculum at the basic and the tertiary level the effects of domestic violence and its negative effects on the society. This will increase awareness and also contribute to the reduction in the incidence of domestic violence.

2. Also, the Effutu Municipal Assembly must put in place sensitization programmes so that the general population will be educated on the negative effects of domestic violence and hence seek more appropriate and acceptable means of settling marital disputes when they arise.

3. The Municipal Assembly must also provide temporal shelters so that victims can seek refuge when the domestic violence occurs at home and when a case of violence reported still undergoing investigation.

4. The Effutu Municipal Assembly should employ professionally trained counsellor for the agencies or institution that deal with issues bordering on domestic violence.

5. The police especially and the other officials whose work include domestic violence need to be retrained on how to handle domestic violence so that they will not take entrenched position when handling such cases. This will also help them to know that this is not just any other case, but a serious case which deserves special attention.

6. Churches, mosques as well as traditionalist should teach their faithfulls 
about the importance of tolerating each other in relationships.

7. Lastly, there must be a hotline so that non-victims of domestic violence can also call and report abuse cases that they may witness in their communities to the police and other appropriate institutions.

\section{Implications for counselling}

1. Victims of domestic violence must be encouraged to access the services of professional counsellors who could help them to overcome the incidence of abuse.

2. Families of victims of domestic violence are also encouraged to report cases of domestic violence to counsellors so that they can invite the victims to come for assistance.

3. Perpetrators of domestic violence must also be referred to professional counsellors for assistance, in order to be helped to do away with their abusive behavior.

4. Counsellors should organize periodic outreaches in order to educate communities on the importance of seeking the service of professional trained counsellors when domestic violence occurs.

\section{REFERENCES}

1 Akintunde, D. O. \& Labeodan (2002). Women and the Culture of Violence in Traditional Africa.Ibadan, Nigeria Sefer Books,.

2 Amaral, R. (2012). Explaining Domestic using Cognitive Behavioural Theory. Psychology for Growth. Retrieved from http://wwwpsychologyfor growth.ca 15/06/2014 at 3:13am

3 Bryman, A. (2001) Social Research Methods (1 ${ }^{\text {st }}$ Ed): London Oxford University Press. Cohen L, Manion L. \& Morrison K. (2003) Research methods in education: Milton Park, Abingdon. Taylor \& Francis.

4 Domestic Violence Act. Ghana (Act, 732). retrieved from http://en.m.wikipedia.org/wiki/d omestic violence on Wednesday, 29/1/2014

5 FIDA Ghana, (2011). The Raging War of Spousal Violence, Retrieved from www.fida.ghana.org/the-raging-war-of-spousalviolence/ on Tuesday, 22/10/2013

6 Flood, M. (2007). Why Violence Against Women and Men Happens and How to Prevent it: $A$ framework and some key strategies.

Retrieved from http://www.awe.asn.au on Wednesday, 2/9/1/2011 at 11:47 a.m.

7 Glaser, B. (1965). The Constant Comparative Method of Qualitative Analysis in Social Problems, 12(4). California Press. Retrieved on Friday, 18/10/13 at 3:23 p.m. from http://www.rangahau.co.n z/analysis/83

8 Hird, M. \& Jackson, S. (2001). Where 'angels' and 'wusses' fear to tread: Sexual coercion in adolescent dating relationships. Journal of Sociology, 32(1), 27-43.

9 Lewis-Beck, M. S., Bryman, A. \& Liao, T. F. (2004). Sequential sampling. The sage encyclopaedia of Social Science. Research methods. Sage Publications Inc.

10 Pettinger L (2002) Qualitative Research; Theory, Method and Practice. London. Sage Publications.

11 Picciano, A (2004) Educational Research Primer (Continuum Research Methods) $1^{\text {st }}$ Ed. Bloombury Academic. New York.

12 Reid, W. H. (2000). Treatment of Antisocial Personality, Psychopathy, and other Characterologic Antisocial Syndromes. Journal of Behavioural Sciences and the Law. Vol. 18, Is. 15, pp647-662.

13 Reynolds, P. D. (1982). Real world research. New Jersey: Prentice-Hall Inc, Englewood

14 Saranrakos, S. (1988). Social Research (2nd ed.) London: Macmillan Press Ltd.

15 Timperly H., Wilson A., Barrer H. \& Fung I.(2007)Teacher Professional Learning \&Development: Best Evidence Synthesis Iteration. Ministry of Education, Australia.

16 Tolman, D., Spencer, R., Reynosa, M. \& Porche, M. (2003). Sowing the seeds of violence in Heterosexual relationships: Early adolescents narrate compulsory heterosexuality. Journal of Social Issues, 59(1), 159-178.

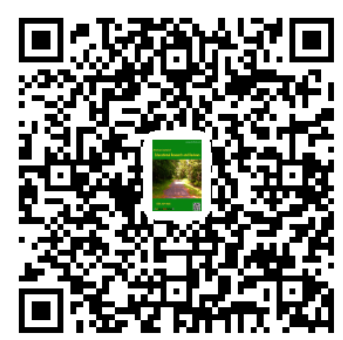

